\title{
POST-UNIFICATION WAGE GROWTH IN EAST GERMANY
}

\author{
Jennifer Hunt
}

Working Paper 6878

http://www.nber.org/papers/w6878

\author{
NATIONAL BUREAU OF ECONOMIC RESEARCH \\ 1050 Massachusetts Avenue \\ Cambridge, MA 02138 \\ January 1999
}

I thank Rachel Friedberg and Ann Huff Stevens for very helpful discussions, Dan Hamermesh, Gur Ofer, and participants at seminars at Cornell, the Federal Reserve Bank of New York, and Yale for comments. I am grateful to Yunning Xu for research assistance, and the Yale Center for International and Area Studies for financial support. The views expressed here are those of the author and do not reflect those of the National Bureau of Economic Research.

(1) 1999 by Jennifer Hunt. All rights reserved. Short sections of text, not to exceed two paragraphs, may be quoted without explicit permission provided that full credit, including ${ }^{(}$ notice, is given to the source. 
Post-Unification Wage Growth in East Germany

Jennifer Hunt

NBER Working Paper No. 6878

January 1999

JEL No. J3, P2

\section{ABSTRACT}

Following monetary union with west Germany in June 1990, the median real monthly wage of prime age east German workers rose by $83 \%$ in six years. I use the German Socio-Economic Panel data to investigate the determinants of this wage growth and some of its implications. For the 1990-1991 period I find that the biggest gainers were low-wage workers generally, and women and the less educated specifically. In the 1991-1996 period the biggest gainers were women and the better educated. Job changing rates were high; a majority of workers had changed jobs by 1996 . The return to job changing, particularly changing to a job in the west, was high in 1990-1991 but fell greatly in the later period, so that overall only $18 \%$ of wage growth was due to job changing within the east, and $7 \%$ to east-west job changing.

Jennifer Hunt

Department of Economics

Yale University

PO Box 208264 - Yale Station

New Haven, CT 06520-8264

and NBER

jennifer.hunt@yale.edu 
Following monetary union with west Germany in June 1990, the median real monthly consumption wage of east German workers aged 18-54 rose by $83 \%$ in six years. The median real product wage rose by $112 \%$. On the other hand, the employment rate fell from $89 \%$ to $73 \%$ for this age group. The overall employment level, influenced by early retirements, fell by about a third between 1989 and 1992, when it stabilized. Although east Germany's employment fall is not striking by European transition economy standards, it is an outlier in terms of wage growth, the least dissimilar country being Poland, where real product wages rose about $25 \%$ in the years following transition. ${ }^{1}$

The east German wage rises, coming on top of the wage rise implicit in the decision to unify the currency at a one for one exchange rate, were pushed through by the powerful union structure imported from the west. The unions could have had several motivations initially, and were not necessarily interested in the welfare of easterners only. One motivation, of which the government approved, was to use wages as the engine of convergence between east and west, in the interests of equity. Other aims may have included restraining immigration from east to west and preventing eastern firms from undercutting western prices. Many economists have inferred a causal link between the post-monetary union wage rises and the employment falls, as well as the low levels of outside investment in the east. Unions counter that wage increases are beneficial as the incentives to invest in human capital are raised. ${ }^{2}$

Some of the aggregate wage arguments have implications for the distribution of wage growth.

1 See Blanchard, Commander and Coricelli (1995).

2 See Burda and Funke (1996) for a model assessing this. 
Since employment falls have been greatest among the initially low paid, particularly women, wage growth should be highest for those of this group remaining employed in order to be consistent with unions reducing employment. This argument also implies that workers with the highest wage rises should be at shrinking firms. Conversely, for wage rises to stimulate human capital investment, presumably the wage rises should be highest for the skilled. The relative wage gains of those moving to the west may be studied to see how the return to moving west changed as eastern wages rose. The extent to which increases in the welfare of east Germans have been tied to moving west is of interest to workers in other transition economies, who face legal and language barriers to similar migration.

Whatever the effects of the high the aggregate wage level, it is important that the distribution of wage gains be conducive to the restructuring of the economy away from heavy industry and industry making poor quality goods towards the service sector and more modern industrial sectors. All formerly communist European countries had a large down-turn in the labor market around 1990, reflecting aggregate shocks such as the loss of export markets. Any long-run recovery is dependent upon a reallocation of resources, which in the short term may prolong the difficulties in the labor market. This reallocation in turn depends on privatization of firms and investment in capital generally, and appropriate returns to moving in the labor market. In the initial disequilibrium period one might hope to see high job turnover accompanied by high returns to moving. In later periods, turnover rates and the return would likely fall. Given the large and enduring employment fall, high mobility rates for those remaining employed would not be enough to make analysts assess the east German labor market positively, but would give more cause for hope than 
if mobility rates were low. Mobility could also be related to employment other than as a reflection of employment reallocation. High mobility might indicate that the flexibility to change jobs was necessary for success in the labor market, and might suggest that some individuals who ceased working did so because they lacked this unobservable flexibility.

In this paper I examine year-to-year wage growth and its relation to individual characteristics, migration, job changing and, where possible, employment. I use longitudinal data from the German Socio-Economic Panel for 1990-1996 for this purpose. Although existing papers examine changes in the returns to characteristics such as education using yearly cross-sections, the huge loss of employment means that the composition of cross-section samples changes a lot, and a different perspective may be gained from longitudinal data. I am not aware of existing papers that exploit the longitudinal aspect of this data (or any other) to examine wage determinants in east Germany.

The determinants of wage growth changed as time progressed. Wage growth between 1990 and 1991 was much higher for those with a low 1990 wage, which was reflected in the larger wage gains of women and those in lower-paid educational groups. The relationship between initial wage and wage growth was weaker for the 1991-1996 period, where year-to-year wage growth was largest for women, the well-educated and younger workers. The relative wage gains of women were small compared to their relative employment losses, however. The relation between initial wage and wage growth, particularly for workers staying with the same employer, points to the influence of unions on the wage structure, as is confirmed by the slower wage growth at firms that in later years withdrew from the bargaining process. However, no relation is found between wage growth 
and employment growth at the worker's firm, although this might be the result of endogeneity.

Job-changing rates are found to be higher than in west Germany, and cumulatively to affect a much larger proportion of workers: of those working in both 1990 and 1996, only $40 \%$ had not moved to a different firm by 1996, compared with $70 \%$ in the western sample. This suggests that considerable restructuring has occurred, and contrasts with the results of Boeri and Flinn (1997), who find low mobility compared with Italy in the Czech Republic, Hungary and Poland. In 19901991 workers moving to the west or changing jobs within the east experienced large wage gains compared to stayers. Even in this period, however, the wage gains of stayers were large enough to dominate overall wage growth. In later years returns to moving fell, as did moving rates. Thus, over the 1990-1996 period only $18 \%$ of wage growth for the sample examined was associated with a job change within the east, while $7 \%$ was due to movement to west Germany to work. The share of wage growth due to job changing for a west German sample was not much lower, at $22 \%$. Although changing jobs was not necessarily the key to large wage gains in any given year, the fact that a majority of those working in both 1990 and 1996 changed jobs suggests that being flexible enough to change may have played an important role in remaining employed at all.

\section{Background and Existing Literature}

Monetary union between east and west Germany took place on 1 July 1990. Some economic changes had been occurring earlier in 1990, but monetary union marked the beginning of the east's shock therapy. The immediate change in the wage system at this time was the conversion 
of east German wage contracts into west German marks at a rate of one for one (Krueger and Pischke 1995). The western trade unions gradually took over the eastern wage bargaining system, and the conversion to the western system was accomplished in most industries over the course of 1991. As this happened, it became common for the unions to negotiate step-wise wage increases designed to achieve convergence to the wage level of the equivalent western industry by 1994 . The contracts varied greatly according to the location and health of the industry, however, and in December 1992 the monthly wages in effect varied from $57.5 \%$ of western levels in the clothing industry to $83 \%$ for construction in east Berlin. When factors such as the longer working week in the east are taken into account, the ratios were somewhat lower. (See Bispinck and Meissner 1993.)

Subsequently, however, as economic conditions continued to be poor, employers reopened negotiations on the contracts, and unions agreed to delay convergence in some cases. Some newly formed firms declined to join the relevant employer federation and were hence not bound by the bargaining, while some other firms simply paid less than the bargained wage. Thus a survey of industrial firms by the Deutsches Institut für Wirtschaftsforschung (German Institute for Economic Research) in the winter of 1993-1994 found that 30\% of firms were paying less than the originally bargained wage in their industry, compared with only 10\% for western industry in a separate 1993 survey. Only $40 \%$ of eastern firms reported belonging to their employer federation. However, large firms were more likely to belong to the employer federation and to respect the bargained wage, so the proportion of workers affected by payment of wages below bargained wages was lower. (Scheremet 1995.) 
At the trough in 1991 GDP was two thirds of its 1989 level. Employment in 1991 was $75 \%$ of the 1989 level of about ten million, and $65 \%$ by 1992, when it stabilized (see Buttler 1997). Note that some of the employment decline occurred before monetary union. The female employment rate fell five percentage points more than the male rate after monetory union (see Hunt 1997). The government adopted two measures designed specifically to deal with employment decline: early retirement and public works jobs. By 1993 866,600 people had retired early, and about 250,000 people were in public works jobs. The western system of short-time work, where workers are put on reduced hours, and have their lost hours compensated at the replacement ratio of unemployment benefits, was widely used, particularly in the first year of the transition (215,000 workers were affected in 1993). Government training programs have also been used (382,000 participants in 1993). (Kühl 1994.) It has been common to ascribe the employment decline to the union wage rises, and some analysts have called for wage subsidies to offset this (Bedau 1996, Bellmann 1994, Begg and Portes 1992). It is worth noting the absence of much empirical support for this link in any country (see, however, Boal and Pencavel 1994).

The most recent available statistics reflect the fact that eastern workers have progressed farther than easterners generally. Eastern GDP per capita for the first half of 1997 was $57 \%$ of the western figure, measured in current prices, while the monthly earnings ratio was about $75 \%$ (and hence the hourly wage ratio was slightly lower, since eastern hours are longer). There was little change in the earnings ratio compared to $1996 .^{3}$

${ }^{3}$ GDP figures come from the Bundesbank web page www.bundesbank.de, population and earnings ratio figures come from the Statistisches Bundesamt web page www.statistik-bund.de/presse/deutsch/pm/p7366042.htm. 
Existing literature on east German wages has focused on cross-section analysis of either the GSOEP or other data sets, often focusing on changing returns to attributes (Bird, Schwarze and Wagner 1994, Krueger and Pischke 1995, Steiner and Puhani 1996). Steiner and Wagner (1997) use Oaxaca decomposition to examine convergence between east and west, and observe that convergence is driven by changes in returns to observable and unobservable characteristics (see also Burda and Schmidt 1997). The results of these papers are not always the same, even when the same data are used, with some finding falling and some rising returns to experience, for example. Hunt (1997) presents only graphical analysis of the longitudinal wage data, but the results appear consistent with a role for unions in the employment decline: wage growth from 1990-1994 was strongly negatively related to the 1990 wage percentile, while the probability of remaining employed was strongly positively related to the 1990 wage percentile. Further, the wage-employment link operated through layoffs, rather than through voluntary separations. This suggests unions may have caused larger employment declines among the less skilled by trying to compress the wage structure. It is interesting to note, however, that wage inequality increased slightly despite the negative relation between initial wage and wage growth.

A literature which has exploited the longitudinal aspect of the GSOEP wage data is the literature on wage and income mobility, generally defined in terms of transitions between quintiles of the distribution. Examples of this rather large literature are Hauser and Fabig (1997) and Steiner and Kraus (1996). The focus on relative wage changes is very different from the focus on absolute wage changes in this paper. 


\section{Econometric Model}

The difficulty with any model of a transition economy is that the correct model changes over time. For example, one would not expect the coefficients on covariates in a wage regression to be the same in 1990, just before monetary union, as in 1996, when something close to a market economy had developed. Inspection of regressions run year by year suggested that the biggest difference was between 1990 and the subsequent years, and that the efficiency gain from pooling subsequent years outweighs possible bias from pooling years with different structural parameters. I therefore propose that differences in wages between years in the 1991-1996 period can be accounted for by changes in the time-varying characteristics $X_{i t}$ and by an individual-specific trend:

$$
\ln w_{i t}=\nu_{1 i}+\gamma_{1 i} t+\beta_{11} X_{i t}+\beta_{12} Z_{i}+\epsilon_{i t} \quad t>90,
$$

where $i$ indexes the worker and the $Z_{i}$ are time-invariant covariates. The time-invariant individualspecific effects $\nu_{i t}$ can be differenced away, leaving individual-specific effects $\gamma_{1 i}$ in the equation for wage growth (due to the assumption of an individual-specific trend in wages):

$$
\ln w_{i t}-\ln w_{i t-1}=\gamma_{1 i}+\beta_{11}\left(X_{i t}-X_{i t-1}\right)+\epsilon_{i t}-\epsilon_{i t-1} \quad t>91 .
$$

In principle I could difference across any number of years, but I choose one year differences so as to include as many workers as possible in the analysis, and so as to exploit more naturally some questions referring to events in the past year.

I hypothesize that the $\gamma_{1 i}$ effects may be predicted by the time-invariant covariates (workers with certain observables are better able to adapt to the transition and achieve a faster wage 
growth):

$$
\gamma_{1 i}=\delta_{1} Z_{i}+\eta_{1 i}
$$

Thus the final equation is:

$$
\ln w_{i t}-\ln w_{i t-1}=\delta_{1} Z_{i}+\beta_{11}\left(X_{i t}-X_{i t-1}\right)+\epsilon_{i t}-\epsilon_{i t-1}+\eta_{1 i} \quad t>91 .
$$

For the 1991-1996 period I thus pool the observations on the pairs of years and assume that all error terms are well-behaved and $\epsilon$ exhibits no serial correlation, for example.

Wages in 1990 can be modelled:

$$
\ln w_{i 90}=\nu_{0 i}+\beta_{01} X_{i 90}+\beta_{02} Z_{i}+\epsilon_{i 90} .
$$

Differencing 1991 and 1990 yields:

$$
\ln w_{i 91}-\ln w_{i 90}=\nu_{1 i}^{\prime}-\nu_{0 i}+\beta_{11} X_{i 91}-\beta_{01} X_{i 90}+\left(\beta_{12}-\beta_{02}\right) Z_{i}+\epsilon_{i 91}-\epsilon_{i 90}, \quad \nu_{1 i}^{\prime}=\nu_{1 i}+91 \gamma_{1 i} .
$$

Similarly to before I hypothesize that $\nu_{1 i}^{\prime}-\nu_{0 i}$ can be predicted with the $Z \mathrm{~s}$ :

$$
\nu_{1 i}^{\prime}-\nu_{0 i}=\delta_{0} Z_{i}+\eta_{0 i}
$$

Thus the final equation for 1990-1991 wage growth is

$$
\ln w_{i 91}-\ln w_{i 90}=\left(\beta_{12}-\beta_{02}+\delta_{0}\right) Z_{i}+\beta_{11} X_{i 91}-\beta_{01} X_{i 90}+\epsilon_{i 91}-\epsilon_{i 90}+\eta_{0 i} .
$$

I estimate these equations using quantile regression, principally median regression. The advantage of median regression is that it is less sensitive to outliers in wage growth, which is important as I have no way of judging in this context what constitutes reasonable wage growth. The use of 
quantile regression at other quantiles sheds light on the distribution of wage growth of different groups. I report bootstrapped standard errors based on 2000 repetitions (1000 in the case of the western sample).

\section{Data}

The data used are from respondents to the German Socio-Economic Panel (GSOEP) who resided in east Germany when that region was first surveyed in June 1990, immediately before monetary union. If these individuals moved to the west they were followed, and are retained in my sample.

The wage used is gross earnings in the month prior to the interview, not adjusted for end of year bonuses. Wages are deflated according to residence in the east or west to give real consumption wages of comparable purchasing power. The time-varying covariates $X$ controlled for in equation (8) include tenure and hours worked per week (the only available hours variable), as well as information on whether the individual changed jobs or region of work (east or west), year dummies and industry of work. The time-invariant $Z$ s include sex, education and age (age is of course not time invariant, but it increments by one each year). To the extent that any of these $Z$ variables do change over time, I use the value of the variable in the earlier of the pair of years. Dummies for the federal state of the worker were always found to be jointly insignificant in the regressions, and are not included in the results presented.

I divide job changers into those who clearly moved involuntarily, and all others (termed voluntary movers). I also classify stayers according to whether their firm's employment had shrunk, 
grown or been stable over the previous year. In 1995, by which time the industry-wide bargaining process had begun to break down, respondents were asked whether their wages were determined by collective bargaining. The influence of this on the wage growth of stayers for 1994-1995 and 1995-1996 can thus be assessed. The data appendix gives more details on the data.

The sample is restricted to those for whom the wage is meaningful in both years of the pair considered. Thus those working in agriculture and fishing in either year or are self-employed in either year are excluded. Also excluded are apprentices (who record very large wage gains when they take up their first real job) and those under 18 or over 53 in the initial year (thus eliminating those who in some years were eligible for early retirement or other benefits at age 55), and those for whom the wage or any of the covariates used were missing. I include in the sample all workers with non-zero hours. I also include those on public works jobs, who are not identifiable in 1991. $3 \%$ of the sample observations for 1992 held a public works job, and the proportion declined subsequently.

For the purposes of some descriptive statistics, I impose the same restrictions but for one year only, so that the wage, for example, need only be valid in the current year rather than in two successive years. I refer to this sample as the yearly sample to distinguish it from the wage growth sample used in the main analysis. I also create yearly and wage growth samples for respondents from the western sample of the panel, for purposes of comparison. 


\section{Descriptive Statistics}

I first use the data as repeated cross-sections using the GSOEP weights to generate time-series for the east. I present information on wages and employment for workers 18-54 and the population 1854 respectively, in Figure 1. The top left hand panel shows the rapid growth of real consumption wages over time at the 25 th, 50 th and 75 th percentile for the yearly sample of workers. The median grew from DM 1627 to DM 2980, a growth of 83\%. (The median wage growth of workers in the yearly sample in both 1990 and 1996 was 89\%.)

From the perspective of labor demand, nominal wages should be deflated with the producer price index to give real product wages. The average of the log product wage, computed for the subset of the yearly sample that is working in the east, is plotted in the upper right panel. It is normalized to equal the average log consumption real wage, which is also plotted, in 1990 . The producer price index grew much less than the consumer price index, so that growth of product wages was much higher even than that of consumption wages. The median 1996 product wage was $112 \%$ higher than the 1990 median.

The lower left hand panel shows the evolution of the employment rate according to different definitions. If only those reporting full-time or part-time work or firm training are considered employed, all the employment reduction (and more) came in the first year. If those sporadically employed or on short-time (including those with zero hours, an oddity of the east) are also considered employed, the reduction was spread over the first two years. If those on short-time with zero hours are not considered employed, the employment fall occurs in the first year. The bottom right hand panel uses average weekly hours including zeros as a proxy for total hours worked in 
the economy, and this measure too shows all the reduction coming in the first year. Also on this graph is average weekly hours for those with positive hours (the yearly sample): east German workers are not experiencing the large hours declines of the west.

Thus, while large wage gains occurred for two to four years, most employment measures show all the employment fall coming in the first year. The timing could still be consistent with a causal connection from wages to employment: employment might have fallen greatly in the first year due to other shocks, but with a free market wage would then have risen gradually. The large wage rises might be keeping stable an employment rate that would otherwise be rising.

Figure 2 plots kernel density estimates of the male and female wage distributions in 1990 and 1996 for the yearly samples in the east (upper panels) and west (lower panels). The left hand panels plot the monthly real consumption wages, while in the right hand panels monthly wages are converted to hourly wages. ${ }^{4}$ The eastern distribution seems to be converging to something somewhat different from the western distribution. The gender difference is smaller in the east, strikingly so for hourly wages, while the male upper tail is much thicker in the west.

Tables $1 \mathrm{a}$ and $1 \mathrm{~b}$ show the means of the variables for the wage growth sample described in the previous section and examined in the rest of the paper, as well as for the corresponding western wage growth sample. The first column gives the mean either of the 1990 level of the variable or of its change from 1990 to 1991 . The second column gives the corresponding means for the pooled pairs of years 1991-1992, 1992-1993 etc. The third column provides statistics on the pooled pairs of years for the 1990-1996 western sample. Annual eastern real wage growth was an enormous 20

\footnotetext{
${ }^{4}$ Monthly wages are regressed on a non-linear function of weekly hours, predicted for average weekly hours, then divided by average weekly hours. This is done for east and west separately.
} 
log points in 1990-1991, and averaged a still large 9 log points in 1991-1996, compared with an average of $4 \log$ points in the western sample. ${ }^{56}$

The most common form of education is the dual-system apprencticeship, which is the omitted category in the regressions below. Vocational training implies training at a vocational school without the practical experience in a firm, and applies to particular occupations, such as those in the health industry. In the east the wage level of apprencticeship graduates is $20-25 \%$ lower than that of otherwise similar vocational training graduates (see Hunt 1997). The "general schooling" category groups those who end their education with neither type of training nor tertiary education. The proportion of workers with only general schooling is much higher in the west.

Eastern tenure fell on average in 1990-1991, but rose on average between pairs of later years. The big flow of workers to the west (this includes both those moving residence, and those merely taking up a commuter job) occurred early on, with 4.5\% moving from 1990-1991. The eastern breakdown according to mover/stayer type shows the fall over time in the proportion of movers and the proportion of workers at firms with stable employment over the previous year, along with an increase in the proportion of shrinking and growing firms (once the missings caused by the lack of information on firm employment in 1994 are taken into account). Western workers appear much less aware of whether their firm is growing or shrinking and there are many more missing

5 Numbers reported for the west, other than regression coefficients, are computed using the GSOEP weights, which make a big difference due to oversampling of western foreigners. The western immigrant sample added to the survey in 1994 is dropped. To avoid using weights in kernel density estimation, western foreigners were dropped from Figure 2.

${ }^{6}$ For western log wages and western hours there is a big difference between the average of the individual changes and the change in the average. Average western wages only grew about $4 \%$ in 1990-1996, while average hours fell over the period. 
values for this variable. The eastern job changing rates are considerably higher than for the west, particularly for involuntary moves. The cumulative effect of the east-west difference over six years is large, probably due not only to differences in the rates but to differences in the prevalence of repeat moving. Of workers in the yearly sample in $1990,85 \%$ in the western sample and $74 \%$ in the eastern sample were working in 1996 . Of these, $70 \%$ in the west but only $40 \%$ in the east had reported each year that they had stayed with the same employer.

Below it shall be found that some eastern workers forced to change jobs involuntarily had wage gains. It should be bourne in mind, however, that $47 \%$ of those losing a job involuntarily between interviews were not working at the next interview date. This number was the same for the west.

Table $1 \mathrm{~b}$ shows the changes in industry composition, which have been significant. The categories given here are those used in the regressions for the sample of movers only, but generally controls for 27 industries are included - however, in the early years several of the service industries have no eastern workers. ${ }^{7}$ The main expansions in the east have been in construction and government. Compared to the west, the east has a higher employment share in construction and transportation, a lower share in industry and private services, and a similar share in government, health and education, science and sport.

Table 1c shows that in the 1994-1996 period 74\% of eastern stayers in the sample still had wages set by collective bargaining, but that $20 \%$ reported setting their wages freely with their employer. $3 \%$ indicated that their wages were not collectively bargained because they were in a group not covered by the contract, $1 \%$ indicated that their wages were not collectively bargained,

${ }^{7}$ I show the breakdown for 1990 and 1995, since I do not require a non-missing 1996 industry for an observation to be valid for 1995-6 wage growth. 
but did not indicate why not, and $3 \%$ had a missing value. The proportion settings wages freely is not as much higher than for the west as was expected. Possibly workers who should have been receiving the bargained wage but were not nevertheless identified with the collectively bargained group.

The sample may be used to calculate the proportion of wage growth attributable to movers, and this proportion is not found to be large. The total wage growth in the sample is computed by adding together the absolute real wage increase in DM between pairs of years for all the observations. For each observation the wage gain may be attributed to a "stay", a job change or to a move to working in the west (since there is overlap I let the moves to working in the west take precedence). There are also some individuals who between pairs of years cease working in the west, which is generally associated with a wage fall. Over the whole 1990-1996 period, only $18 \%$ of the wage growth is due to job changes within the east, and $7 \%$ (net of returns) is due to movement to the west. Only for 1990-1991 is the total share of changers considerably higher, due to the larger gains from moving west: $15 \%$ due to job changes in the east, and $18 \%$ due to movement to the west. ${ }^{8}$ A similar calculation for the west reveals that $22 \%$ of wage growth is due to job changes.

The magnitude of the wage gain achieved between any two years appears to be importantly related to the wage in the initial year, particularly in 1990-1991. Figure 3 presents for 1990-1991 and the pooled pairs of years 1991-1996 the Nadaraya-Watson non-parametric kernel regression of the change in the log wage between the pair of years on the initial level of the wage. The

\footnotetext{
8 The analysis can be performed on changes in log wages and the results are very similar.
} 
Epanechnikov kernel is chosen, along with a bandwidth of .05 and a grid of 100 points. To avoid odd results from using a fine bandwidth at the tails I did not use the top and bottom $1 \%$ of the initial wage observations. The relationship seems to be fairly linear, showing that those with initially low wages had the highest wage growth. In the regressions below I will attempt to capture this relationship using covariates other than the initial wage.

\section{Results}

\subsection{Whole Sample}

Table 2 shows median regressions for eastern wage growth for the 1990-1991 period. These and all future regressions control for the worker's gender, age, and education in the initial year, here 1990. In the first column the change in tenure is a covariate, while in later columns tenure in 1991 is replaced by direct information on whether a worker moved or not. In the third column dummies for industry in the initial year are added, and in the fourth column the change in weekly hours is added, which is appropriate if one is more interested in hourly wages than monthly earnings. In the fifth column I add the log of the initial wage to the covariates (except change in weekly hours), to see to what extent the covariates have captured the relation of Figure $3 .^{9}$

In column 1 the coefficient on the female dummy is insignificant while the coefficient on age

9 According to the model presented, tenure and hours in 1990 and 1991 should be entered separately. Nevertheless, since it changes the results imperceptibly, I use the difference as it is easier to interpret. One cannot generally reject the hypothesis that the hours coefficients may be entered in differenced form. 
is negative and significant although somewhat small: an age difference of ten years implies a 1.2 log point (or about 1.2\%) difference in wage growth. Using a quadratic in age did not appear to capture the relationship better. The coefficients on the education dummies indicate that wage gains were inversely proportional to education: those with vocational training, a group better paid than the omitted apprenticeship group, had $5 \%$ lower wage growth, the highly educated university group had $8 \%$ lower growth, while the small poorly educated general schooling group had $10 \%$ higher wage growth. These results are consistent with the larger wage rises being amongst those with initially lower wages, as was illustrated in Figure 3.

The coefficient on change in tenure in column 1 is negative, indicating beneficial effects of a job change, but insignificant. Adding a term in tenure squared did not appear to capture the relationship better. By contrast, a move to the west (without taking the loss of tenure into account) increased wages by a massive $42 \log$ points.

Column 2 indicates that voluntary movers gained a statistically significant $14 \log$ points. Since moving to the west is controlled for, the magnitude indicates the gain to changing employer within the east. The coefficient on involuntary moving is insignificant. ${ }^{10}$ The coefficient on moving west indicates a $36 \log$ point gain. In this period it is appropriate to think of the typical mover to the west as one having voluntarily separated from a previous employer, and such a person would thus gain about $50 \log$ points. The coefficients on the moving dummies should not be interpreted as the return to an exogenous move by a random worker, since voluntary and involuntary movers

\footnotetext{
${ }^{10}$ Notice that the voluntary moving category probably contains many misclassified involuntary movers, and its coefficient is therefore probably biased down. The involuntary movers category probably has few misclassified workers (see the data appendix).
} 
are likely to be unobservably different from each other and from stayers. In the specification of column 2, as in the others in the table, the coefficient on tenure in 1990 is insignificant.

The addition of industry dummies in column 3 makes the female dummy positive and significant, indicating $4 \%$ higher wage growth for women compared to men in the same industry. The point estimates on the university dummy and on the vocational training dummy fall and the coefficient on the latter becomes insignificant. The coefficient on general schooling is also insignificant in this column. ${ }^{11}$

Column 4 adds the change in hours between 1990 and 1991 to the covariates. Not surprisingly, the coefficient on hours changes is positive and very significant. Controlling for hours reduces the magnitudes of the coefficients on the moving variables, although not significantly, but the coefficient on moving voluntarily becomes insignificant. The direction of the change suggests that movers may have increased their hours relative to stayers, the latter having perhaps been put on short time.

The log wage is negative and extremely significant in column 5 , and the $R^{2}$ rises considerably compared to column 3, suggesting the other covariates were not fully picking up the relationship of Figure 3. The coefficient implies that a $10 \%$ higher initial wage is associated with a $3.3 \log$ point lower wage growth, a fairly substantial magnitude. Controlling for the wage causes the coefficients on gender and education to flip sign: this presumably indicates that amongst those with a similar wage in 1990, males and the well-educated were more likely to be experiencing a temporary bad

11 I have run a regression where I add dummies for the worker's second year industry to the covariates of this column 3 specification (these results are not reported). This renders the coefficient on moving voluntarily very small and insignificant, indicating that all the benefit of moving is coming from changing industry. 
draw and hence to improve in the next period. Speculation about the meaning of the coefficient on the wage is deferred until the next section.

Columns 1 and 2 of Table 3 repeat the specification of column 3 in Table 2 but using quantile regression at the .25 and .75 quantiles rather than median regression. The sample remains the same. This reveals some interesting differences in the distribution of wage growth by stayer/mover type, although the differences are not always significant. The gain to working in the west appears higher at the 75th percentile than at lower percentiles. The gap between the wage growth of stayers and movers within the east similarly grows as the percentile considered rises. The 75th percentile voluntary mover gained a huge $26 \log$ points with respect to the 75 th percentile stayer, compared to only a $7 \%$ and insignificant gain at the 25 th percentile.

Table 4 repeats the regressions of Table 2 for the observations on the pooled pairs of years from 1991 to 1996, with year dummies added to all the regressions, and a dummy indicating whether the worker was in the west in the initial year of the pair. Such workers would get only western wage growth, which is lower. In these regressions "tenure" or "log wage" refers to the level of the variable in the earlier of the pair of years to which the observation refers.

The female dummy is positive and significant in the regressions which do not control for the wage. This is consistent with the finding in Hunt (1997) that although the male-female wage gap is being closed partly through the exit from employment of low-paid women, some of the closing is genuinely beneficial to women remaining employed. Again, in column 5, when the log wage is controlled for, the coefficient on the female dummy flips to negative and significant. The coefficient on the log wage itself is lower for the later period than for 1990-1991. The coefficient on age is 
negative and significant across the specifications, but small.

The coefficients on the education dummies are somewhat different from those in the 1990-1991 regressions, since in columns 1 and 2 it is university graduates who appear to experience significantly larger wage gains than the omitted apprenticeship graduates. The magnitude is smaller than the educational differences found for 1990-1991. As for the earlier period, the education dummies are weakened by the addition of industry dummies in column 3 and 4 .

The coefficient on change in tenure (column 1) is insignificant. In the other columns of Table 4 initial tenure has a positive and generally insignificant coefficient. The bonus achieved by moving to the west fell over time, as wages in the west rose a little and wages in the east rose a lot, and this is reflected in the much smaller coefficient on the dummy for moving to the west in 1991-1996, indicating $5-6 \%$ wage growth. Due to the fall in the point estimates, these coefficients are in fact statistically insignificant. ${ }^{12}$ Workers in the west in the initial year have $4-6 \%$ lower wage growth.

The coefficients on voluntary and involuntary moves in columns 2-4 are also generally insignificant. The point estimates indicate that the wage growth advantage of voluntary movers over stayers has fallen greatly from 6-14\% in 1990-1991 to only 1-3\% here. Furthermore, involuntary movers now have a median wage growth $3-5 \%$ below that of stayers in columns $2-4$ (the difference is significant in column 2). Voluntary and involuntary movers are significantly different from each other in column 2, and in column 3 at the $10 \%$ level. In this period, amongst movers to the west, stayers (workers transferred to the western plant of a parent firm) are more common than voluntary or involuntary movers. These workers gained the (insignificant) $5-6 \%$ indicated by the

${ }^{12}$ Note that the corresponding coefficients in mean regressions are significant. 
coefficient on the coefficient on moving west, while the wage gain for a voluntary mover to the west was $8-9 \%$, the sum of the moving west and voluntary moving coefficients. This sum is significant at the $10 \%$ level in columns 2 and 3 .

Columns 3 and 4 of Table 3 report analysis of the 25th and 75th percentiles for the specification of column 3 in Table 4. These results show that the wage growth distribution of movers is wider than that of stayers. The 25 th percentile of both voluntary and involuntary movers is a significant 8-10\% below that of stayers, while the 75 th percentile of voluntary movers is $16 \log$ points higher. The 75th percentile of involuntary movers is insignificantly different from that of stayers, and the coefficient is positive.

The results for columns 3 and 4 in Tables 2 and 4 may be compared with the results for the western sample in columns 1 and 2 of the Appendix Table. Wage growth differences by educational group are smaller in the west. Voluntary movers gain $4-5 \%$ in the west, more than in the later eastern period, while western involuntary moving losses are smaller than those of the later eastern period, but also insignificant. ${ }^{13}$

\subsection{Stayers and Movers Separately}

The results of Tables 2-4 have revealed some interesting results about the distribution of wage gains for movers relative to stayers, but since it has been shown that most wage growth, particularly in later years, has been within job, it is worthwhile to examine the stayers more closely. In

\footnotetext{
${ }^{13}$ Bender et al. (1998) and Burda and Mertens (1998) find only small wage losses for displaced west German males who were subsequently re-employed.
} 
particular, it is of interest to know whether wage growth was positively or negatively correlated with employment growth at the firm. This analysis is carried out for 1990-1991 in Table 5, columns 1-3, using median regression. Column 1 controls for neither industry nor hours change, while column 2 controls for both. Notice that in principle a worker can move to the west while being a "stayer" if he or she transfers within the same firm. The coefficients on sex, age, education and tenure in these columns are somewhat similar to those in Table 2 for all workers.

When industry and hours are not controlled for, in column 1, the coefficient on the dummy for being at an expanding rather than stable firm is positive, significant, and large. It implies that a worker at such a firm gained 15 log points compared to a worker at a firm with stable employment, the opposite of what would be expected if firms with higher union wage rises are suffering greater employment declines. The coefficient on being at a shrinking firm is insignificant, however, as is the coefficient on staying at a firm whose employment change is unknown.

As mentioned, however, unions took into account the fortunes of the industries in deciding on the industry-wide wage rises, so it is not generally valid to exploit between-industry variation in change in firm size. In the 1990-1991 period, wage rises granted by firms before the new industrywide unions were established may have led to within-industry variation in wage growth, although this variation may be similarly endogenous. Also, from a labor demand stand-point, it is hourly wages that are relevant, so the change in hours should be controlled for. Column 2 shows that controlling for industry and hours renders the coefficient on staying with a growing firm small and insignificant. In column 3 the initial wage, but not hours, is controlled for, yielding a coefficient on the wage slightly smaller than that in Table 2. 
The first three columns of Table 6 examine stayers in the 1991-1996 period, using the same specifications as in Table 5. Later in the 1991-1996 period there should be within-industry variation in wage rises due to the break-down of the bargaining system. The coefficients on gender, age, education, working in the west in the initial year and wage are similar in the first two columns to the coefficients in the corresponding columns of Table 4. The coefficients on change in firm employment are not significant in any of the three specifications. It should be noted that, particularly in comparison with the huge average wage rises, the standard errors are small, so that even quite small differences between the firm types can be ruled out. However, it is possible that the firms leaving the bargaining process have been those that would have had the worst employment growth, and the benefit of lower wages merely brings them back to average employment growth. ${ }^{14}$

Columns 4 and 5 of Tables 5 and 6 analyze the movers separately from the stayers. In column 5 the wage is added to the specification of column 4 - both include industry dummies, but exclude the change in hours. Among movers, women do not appear to have higher wage growth (column 4).

Comparison of the results for movers and stayers indicates that workers reporting both moving their workplace to the west and staying with the same employer do not experience wage gains, while those changing employer voluntarily as they move to the west experience large and significant gains compared to voluntary movers within the east: $26 \log$ points in 1990-1991 and $15 \log$ points in 1991-1996 (column 4, Tables 5 and 6 respectively). This indicates that the growing share of "transfer" movers to the west contributed (in a mechanical sense) to the fall in the return to

\footnotetext{
${ }^{14}$ To make pronouncements in connection with labor demand, those stayers who are staying in the west should be dropped from the sample. Doing so makes no difference to the firm employment coefficients.
} 
moving west as calculated for the whole sample. ${ }^{15}$

Another interesting difference between the movers and the stayers is the coefficient on the wage (column 5), which is significantly more negative for movers in both periods, although the difference is much larger in the later period. The coefficient on the log wage will be biased down by measurement error, and could also represent a reversion to the mean tendency that might be present in all countries. It is therefore informative to compare the reported eastern coefficients on the wage with their counterparts from similar western regressions for 1990-1996 (reported in the Appendix Table columns 3-5). The western coefficient for the full sample and the subsample of stayers is between -0.05 and -0.03 , while for the subsample of movers the coefficient is -0.48 (all coefficients are very significant). Together the results suggest that measurement error leads to a small and significant negative coefficient on the wage, that some sort of reversion to the mean process among movers leads to a large negative coefficient on the wage, and that something particular is happening among eastern stayers, leading to an unusually large negative coefficient for this sample.

The wage rises for those eastern stayers with initially low wages should be viewed with the huge employment fall for initially low earners in mind. The coefficient on the log wage could represent an effort by the unions to keep the wage distribution compressed, which had large employment falls as a side-effect. Alternatively, it is possible that high wage workers were hoarded by firms in the initial shock, despite a fall in the immediate need for all types of worker, and that those

\footnotetext{
${ }^{15}$ In Table 5 column 1 the point estimate for "transfer" movers is large (although insignificant). Unreported results indicate that adding industry dummies even without adding the change in hours reduces the coefficient to the magnitude of column 2 .
} 
few low wage workers retained were retained due to a new recognition of their qualities, and these workers then enjoyed large wage gains. Both of these stories are consistent with a large but falling wage coefficient magnitude amongst eastern stayers compared to western stayers.

In Table 7 I use 1994-1995 and 1995-1996 stayers only, and add the information on wage bargaining. The first column adds the bargaining covariates to the covariates of Table 6 column 2 , and thus includes industry dummies. In column 2 the change in hours is also controlled for, since in this situation hourly wages are probably the variable of most interest. In column 3 the log wage is controlled for in addition. The results presented show that within industry the minority of workers setting wages freely with their employer had statistically significantly lower wage growth by about $2 \%$ than those with bargained wages, the excluded category, in the preferred specification of column 2. This magnitude should be compared with the average annual wage growth for the 1994-1996 period of 5\%, but seems lower than might have been expected. If the comparison bargained wage group is contaminated by respondents whose employer is violating the agreement with the union, the coefficient of interest may be biased toward zero. Those individuals whose occupation was excluded from the wage bargaining at their firm (typically upper level employees) did not have significantly different wage growth from those with bargained wages.

I have run a regression interacting the dummy for setting wages freely with education, to test whether unions help the less skilled more. I do not find significant differences by education, possibly due to the small cell sizes (these results are not reported). 


\section{$6 \quad$ Summary and conclusions}

In the six years following monetary union, consumption real wages in east Germany rose by $83 \%$, and real product wages by $112 \%$. Wage growth is potentially the driving force behind convergence, but possibly the cause of large employment losses. For 1990-1991 in particular the largest wage rises were for those with an initially low wage. This is to some extent picked up by the other covariates: women and those in lower-paid educational groups had larger wage gains. The relation between initial wage and wage growth is not as strong in later years, and the groups with the largest wage rises were women, those with tertiary education and younger workers. The greater wage gains of the initially low paid, particularly stayers, and the fact that in recent years workers with wages set by collective bargaining have had faster wage growth than other workers, seem consistent with unions having a large effect on the wage structure. However, wage rises were found to be similar at growing, shrinking and stable firms. Wage growth and employment growth should be negatively correlated if wage rises reduce employment, but endogeneity may be an issue.

Of workers employed in both 1990 and 1996, only 40\% were with the same firm in 1996 as in 1990, compared with $70 \%$ in the western sample. This high mobility rate should be a sign that the economy is progressing well with restructuring, but this must be weighed against the large employment falls that have occurred. In spite of high mobility, over the period 1990-1996 only $18 \%$ of wage growth was attributable to job changes within the east, and $7 \%$ to moves to working in the west. For 1990-1991 15\% of growth was due to within-east moves and $18 \%$ to moves to the west. This compares with a share of $22 \%$ for job-changing in the western sample. Thus although changing jobs was not necessarily the key to large wage gains in any given year, 
the high mobility rate over the whole period suggests that having the flexibility to change jobs might be an important generally unobserved determinant of being employed at all.

The returns to moving were high in 1990-1991, but fell over time, as did mobility rates. Movers voluntarily leaving their employer to go to the west in 1990-1991 had wage growth 50 log points higher than those staying in the east. As eastern wages rose relative to western, however, the gain to such a move fell to about 8-9\% (significant at the 10\% level) averaged over 1991-1996. Workers transferring west within the firm experienced no wage gain, and an increase in their share of movers to the west also contributed to the fall in the gain to moving west. Amongst voluntary job changers, those moving west in 1991-1996 gained a significant 15 log points relative to those moving within the east, compared to $26 \log$ points in 1990-1991. As for those changing firm within the east, in 1990-1991 involuntary movers had median wage growth insignificantly different from that of stayers, while voluntary movers gained 10-14 log points over stayers. In the period 19911996, however, voluntary movers' advantage had fallen to an insignificant 1-3\%, while involuntary movers had an insignificant 3-5\% lower wage growth than stayers.

Examination of quantiles other than the median reveals that the gain to moving voluntarily within the east was higher at the 75th percentile than at lower quantiles in both 1990-1991 and 1991-1996. In fact, in 1991-1996 both voluntary and involuntary mover wage growth were lower at the 25 th percentile than wage growth of stayers. The gain to working in the west was higher at the 75th percentile than at lower percentiles in 1990-1991. 


\section{Data Appendix}

The wage used is gross earnings in the month prior to the interview, not adjusted for end of year bonuses. Wages for respondents living in the west are adjusted using the western consumer price index $(1991=100)$. The eastern consumer price index is adjusted so that a meaningful comparison of the price levels between east and west may be made, using the results of a 1991 study of the relative price levels in the east and west (Krause 1994). The wages of those living in the east are thus deflated with this adjusted index, so that the real wages of those in the east and west should have comparable purchasing power. It should be noted, however, that the price index for the east in 1990 is not considered as reliable as in the subsequent years.

In my analysis I exploit information about changing jobs, and moving or commuting to the west. Each year respondents are asked whether any change has occurred in their job, and if so what type of change and the reason for its occurring. Possible changes include a job change within the firm and the take-over of the firm by another. I generally group both of these with the group with no change. I do not consider take-overs separately because the phrasing of the question about whether a change has occurred seems likely to induce many respondents experiencing a take-over to answer that no change had occurred. Also, examination of separate questions on firm ownership and founding date suggests respondents are confused on this subject (as they tend to change their answers from year to year in the absence of any change in their job). 6\% of the 1990-1991 and 1.5\% (per year) of the 1991-1996 sample reported a firm take-over. For job-changing rates within the firm the corresponding figures were $6 \%$ and $3 \%$. Those respondents who reply that they changed job because they were laid off or fired or their firm closed I categorize as involuntary movers. All remaining respondents, which include some whose voluntary nature is ambiguous, I categorize as "voluntary" movers.

Whether a respondent is living in the west should be well measured, as it is recorded by the survey takers. Whether a respondent is commuting to the west is a question asked separately from the moving questions described above. I group those living in and commuting to the west into the variable indicating working in the west.

In addition to classifying movers, I also classify stayers according to whether they reported that employment at their firm had been growing, shrinking or stable over the previous year. This question was not asked in 1994, however. Stayers who changed job within a firm or who stated that their firm was taken over are assigned a missing bargaining status, since their bargaining status could have changed. 


\section{References}

Allison, Christine and Dena Ringold. 1996. "Labor Markets in Transition in Central and Eastern Europe." World Bank Technical Paper No.352 Social Challenges of Transition Series.

Bedau, Klaus-Dietrich. 1996. "Löhne und Gehälter in Ost- und Westdeutschland gleichen sich an, Lohnstückkosten jedoch nicht." DIW Wochenbericht.

Begg, David and Richard Portes. 1992. "Eastern Germany Since Unification: Wage Subsidies Remain a Better Way." CEPR Discussion Paper 730.

Bellmann, Lutz. 1994. "Plädoyer für Lohnkostensubventionen in den neuen Bundesländern." In Hubert Heinelt et. al. eds. Arbeitsmarktpolitik nach der Vereinigung. Edition Sigma, Berlin.

Bender, Stefan, Christian Dustmann and Costas Meghir. 1998. "Job Displacement, Nonemployment and Wages in Germany." University College London working paper.

Bird, Edward, Johannes Schwarze and Gert Wagner. 1994. "Wage Effects of the Move Toward Free Markets in East Germany." Industrial and Labor Relations Review, pp.390-400.

Bispinck, Reinhard and Werner Meissner. 1993. "Die Tariflohnentwicklung in Ostdeutschland." In Renate Neubäumer ed. Arbeitsmarkpolitik Kontrovers: Analysen und Konzepte für Ostdeutschland, Wissenschaftliche Buchgesellschaft, Darmstadt.

Boal, William and John Pencavel. 1994. "The Effects of Labor Unions on Employment, Wages, and Days of Operation: Coal Mining in West Virginia." Quarterly Journal of Economics, pp.267-298.

Boeri, Tito and Christopher Flinn. 1997. "Returns to Mobility in the Transition to a Market Economy." C.V. Starr Center for Applied Economics, Economic Research Report 97-41.

Burda, Michael and Michael Funke. 1996. "Wages and Structural Adjustment in the New German States." Humboldt University SFB 373 Discussion Paper 99.

Burda, Michael and Antje Mertens. 1998. "Wages and Worker Displacement in Germany." Humboldt University working paper.

Burda, Michael and Christoph Schmidt. 1997. "Getting Behind the East-West Wage Differential: Theory and Evidence." University of Heidelberg Discussion Paper 250.

Buttler, Friedrich. 1997. "Globales Arbeitsmarktungleichgewicht und Arbeitsmarktpolitik im Einigungsprozess." In Doris Beer et. al. eds. Der ostdeutsche Arbeitsmarkt in Gesamtdeutschland: Angleichung oder Auseinanderdriften?, Leske und Budrich, Opladen. 
Hauser, Richard and Holger Fabig. 1997. "Labor Earnings and Household Income Mobility in Reunified Germany: A Comparison of the Eastern and Western States." Center for Policy Research, Syracuse University Income Security Policy Series No.15.

Hunt, Jennifer. 1997 "The Transition in East Germany: When is a Ten Point Fall in the Gender Wage Gap Bad News?", NBER Working Paper 6167.

Krause, Peter. 1994. "Armut im Wohlstand: Betroffenheit und Folgen." Deutsches Institut für Wirtschaftsforschung Discussion Paper 88.

Krueger, Alan and Jörn-Steffen Pischke. 1995. "A Comparative Analysis of East and West German Labor Markets: Before and After Unification." In Richard Freeman and Lawrence Katz eds. Differences and Changes in Wage Structures, University of Chicago Press, Chicago.

Kühl, Jürgen. 1994. "Zur Veränderung der arbeitsmarktpolitischen Instrumente seit 1990." In Hubert Heinelt et. al. eds. Arbeitsmarktpolitik nach der Vereinigung. Edition Sigma, Berlin.

Scheremet, Wolfgang. 1995. "Tarifpolitik in Ostdeutschland: Ausstieg aus dem Lohnverhandlungsmodell der Bundesrepublik Deutschland." Zeitschrift für angewandte Wirtschaftsforschung - Applied Economics Quarterly, pp.135-169.

Steiner, Viktor and Florian Kraus. 1996. "Aufsteiger und Absteiger in der ostdeutschen Einkommensverteilung: 1989-1993." In Martin Diewald and Kark Ulrich Mayer eds. Zwischenbilanz der Wiedervereinigung. Leske und Budrich, Opladen.

Steiner, Viktor and Patrick Puhani. 1997. "Economic Restructuring, the Value of Human Capital, and the Distribution of Hourly Wages in Eastern Germany 1990-1994." Vierteljahrshefte zur Wirtschaftsforschung, pp.197-210.

Steiner, Viktor and Kersten Wagner. 1997. "East-West German Wage Convergence - How Far Have We Got?" ZEW Mannheim Discussion Paper No.97-25. 
Table 1a: Means of Individual Characteristics

(Standard Deviations in Parentheses)

\begin{tabular}{|c|c|c|c|}
\hline & $1990-1991$ & 1991-1996 & $\begin{array}{c}1990-1996 \\
\text { West }\end{array}$ \\
\hline ) Log wage & $0.20 \quad(.27)$ & $0.09(.23)$ & $0.04 \quad(.22)$ \\
\hline Log wage & $7.39(0.36)$ & $7.82(.40)$ & $8.07(.57)$ \\
\hline Sex (female=1) & $0.51 \quad(.50)$ & $0.48 \quad(.50)$ & $0.40 \quad(.49)$ \\
\hline Age & $37.3(9.1)$ & $37.4 \quad(8.8)$ & $36.9(9.1)$ \\
\hline General schooling? & $0.03 \quad(.17)$ & $0.02 \quad(.15)$ & $0.15(.36)$ \\
\hline University? & $0.11(.32)$ & $0.13(.33)$ & $0.15(.35)$ \\
\hline Apprenticeship? & $0.60 \quad(.49)$ & $0.59(.49)$ & $0.46(.50)$ \\
\hline Vocational training? & $0.25(.44)$ & $0.26(.44)$ & $0.24 \quad(.43)$ \\
\hline Tenure (months) & $140 \quad(110)$ & $104 \quad(107)$ & $98.3 \quad(81.7)$ \\
\hline ) Tenure & $-7.3(58.3)$ & $4.3 \quad(36.6)$ & $6.5 \quad(19.1)$ \\
\hline Working in west? & 0 & $0.09 \quad(.29)$ & -- \\
\hline ) Working in west? & $0.045 \quad(.206)$ & $0.005 \quad(.176)$ & -- \\
\hline Hours work per week & $43.3(8.0)$ & $42.5 \quad(8.7)$ & $39.0 \quad(10.4)$ \\
\hline $\begin{array}{l}\text { ) Hours work per } \\
\text { week }\end{array}$ & $-2.8 \quad(8.9)$ & $0.4 \quad(7.1)$ & $0.1 \quad(6.3)$ \\
\hline $\begin{array}{l}\text { Stay with stable } \\
\text { firm? }\end{array}$ & $0.58 \quad(.49)$ & $0.33(.47)$ & $0.19(.39)$ \\
\hline $\begin{array}{l}\text { Stay with growing } \\
\text { firm? }\end{array}$ & $0.04 \quad(.21)$ & $0.13(.33)$ & $0.10(.30)$ \\
\hline $\begin{array}{l}\text { Stay with shrinking } \\
\text { firm? }\end{array}$ & $0.21(.40)$ & $0.25(.43)$ & $0.29(.46)$ \\
\hline $\begin{array}{l}\text { Stay with unknown } \\
\text { firm type? }\end{array}$ & $0.02(.13)$ & $0.20(.40)$ & $0.34 \quad(.47)$ \\
\hline Move voluntarily? & $0.07 \quad(.26)$ & $0.05 \quad(.21)$ & $0.05 \quad(.22)$ \\
\hline Move involuntarily? & $0.07 \quad(.26)$ & $0.04 \quad(.19)$ & $0.01(.11)$ \\
\hline Move reason unknown? & $0.01 \quad(.08)$ & $0.01(.10)$ & $0.01(.08)$ \\
\hline Observations & 1323 & 5653 & 14603 \\
\hline
\end{tabular}

Notes:

a. In the first column the mean of differenced variables is the mean of the 1990-1991 difference. In the second column the mean of the 1991-1992, 1992-1993 etc. differences are given. Undifferenced means refer to the first of the pair of years. b. Western means are weighted with sample weights. 
Table 1b: Distribution of Employment by Industry

\begin{tabular}{llll}
\hline \hline & 1990 & 1995 & 1995 West \\
\hline Mining/quarrying/energy & 0.07 & 0.03 & 0.02 \\
Chemicals/synthetics & 0.04 & 0.03 & 0.05 \\
Iron/steel & 0.05 & 0.05 & 0.07 \\
Mechanical engineering & 0.06 & 0.05 & 0.08 \\
Electrical engineering & 0.07 & 0.03 & 0.05 \\
Wood/paper/leather/ & 0.08 & 0.05 & 0.06 \\
textiles/food & 0.08 & 0.15 & 0.06 \\
Construction & 0.10 & 0.11 & 0.12 \\
Retail/wholesale trade & 0.11 & 0.09 & 0.06 \\
Transportation & 0.04 & 0.07 & 0.10 \\
Private services & 0.12 & 0.08 & 0.08 \\
Education/science/sport & 0.09 & 0.09 & 0.09 \\
Health & 0.09 & 0.16 & 0.15 \\
Government & 1323 & 1111 & 2428 \\
\hline Observations & & & \\
\hline \hline
\end{tabular}

Table 1c: Distribution of Wage Bargaining Status for Stayers

\begin{tabular}{lcc}
\hline \hline & $1994-1996$ & $1994-1996$ West \\
\hline Wages collectively bargained & 0.74 & 0.75 \\
In uncovered group & 0.03 & 0.05 \\
Wages set freely & 0.20 & 0.16 \\
Wages not bargained, reason & 0.01 & 0.01 \\
why not is missing & & 0.03 \\
Bargaining information missing & 0.03 & 4626 \\
\hline Observations & 2069 & \\
\hline \hline
\end{tabular}


Table 2: Determinants of Wage Growth 1990-1991 (Standard Errors in Parentheses)

\begin{tabular}{|c|c|c|c|c|c|}
\hline & (1) & $(2)$ & (3) & $(4)$ & $(5)$ \\
\hline Log wage & -- & -- & -- & -- & $\begin{array}{l}-0.334 \\
(0.037)\end{array}$ \\
\hline Sex (female=1) & $\begin{array}{c}0.012 \\
(0.012)\end{array}$ & $\begin{array}{l}0.011 \\
(0.011)\end{array}$ & $\begin{array}{c}0.037 \\
(0.013)\end{array}$ & $\begin{array}{c}0.038 \\
(0.015)\end{array}$ & $\begin{array}{l}-0.033 \\
(0.016)\end{array}$ \\
\hline Age & $\begin{array}{l}-0.0012 \\
(0.0006)\end{array}$ & $\begin{array}{l}-0.0010 \\
(0.0009 \\
\quad\end{array}$ & $\begin{array}{c}-0.0011 \\
(0.0008)\end{array}$ & $\begin{array}{l}-0.0008 \\
(0.0009)\end{array}$ & $\begin{array}{l}-0.0005 \\
(0.0008)\end{array}$ \\
\hline $\begin{array}{l}\text { General } \\
\text { schooling? }\end{array}$ & $\begin{array}{c}0.101 \\
(0.049)\end{array}$ & $\begin{array}{l}0.090 \\
(0.052)\end{array}$ & $\begin{array}{c}0.098 \\
(0.054)\end{array}$ & $\begin{array}{c}0.113 \\
(0.062)\end{array}$ & $\begin{array}{l}-0.037 \\
(0.053)\end{array}$ \\
\hline University? & $\begin{array}{l}-0.078 \\
(0.015)\end{array}$ & $\begin{array}{l}-0.080 \\
(0.015)\end{array}$ & $\begin{array}{l}-0.053 \\
(0.020)\end{array}$ & $\begin{array}{l}-0.058 \\
(0.022)\end{array}$ & $\begin{array}{c}0.059 \\
(0.025)\end{array}$ \\
\hline $\begin{array}{l}\text { Vocational } \\
\text { training? }\end{array}$ & $\begin{array}{l}-0.049 \\
(0.013)\end{array}$ & $\begin{array}{l}-0.046 \\
(0.012)\end{array}$ & $\begin{array}{l}-0.018 \\
(0.013)\end{array}$ & $\begin{array}{l}-0.032 \\
(0.014)\end{array}$ & $\begin{array}{c}0.062 \\
(0.016)\end{array}$ \\
\hline ) Tenure/1000 & $\begin{array}{l}-0.175 \\
(0.219)\end{array}$ & -- & -- & -- & -- \\
\hline Tenure/1000 & -- & $\begin{array}{l}0.008 \\
(0.069)\end{array}$ & $\begin{array}{l}-0.070 \\
(0.068)\end{array}$ & $\begin{array}{l}-0.031 \\
(0.071)\end{array}$ & $\begin{array}{c}0.055 \\
(0.071)\end{array}$ \\
\hline $\begin{array}{l}\text { ) Working in } \\
\text { west? }\end{array}$ & $\begin{array}{c}0.417 \\
(0.058)\end{array}$ & $\begin{array}{l}0.358 \\
(0.068)\end{array}$ & $\begin{array}{c}0.288 \\
(0.072)\end{array}$ & $\begin{array}{c}0.299 \\
(0.066)\end{array}$ & $\begin{array}{c}0.345 \\
(0.065)\end{array}$ \\
\hline $\begin{array}{l}\text { Move, } \\
\text { voluntarily? }\end{array}$ & -- & $\begin{array}{l}0.137 \\
(0.044)\end{array}$ & $\begin{array}{c}0.110 \\
(0.050)\end{array}$ & $\begin{array}{c}0.063 \\
(0.043)\end{array}$ & $\begin{array}{c}0.093 \\
(0.043)\end{array}$ \\
\hline $\begin{array}{l}\text { Move, } \\
\text { involuntarily? }\end{array}$ & -- & $\begin{array}{l}0.033 \\
(0.036)\end{array}$ & $\begin{array}{c}0.042 \\
(0.031)\end{array}$ & $\begin{array}{c}0.031 \\
(0.034)\end{array}$ & $\begin{array}{c}0.046 \\
(0.030)\end{array}$ \\
\hline $\begin{array}{l}\text { Move, reason } \\
\text { unknown? }\end{array}$ & -- & $\begin{array}{l}0.220 \\
(0.203)\end{array}$ & $\begin{array}{c}0.242 \\
(0.204)\end{array}$ & $\begin{array}{c}0.272 \\
(0.216)\end{array}$ & $\begin{array}{c}0.101 \\
(0.162)\end{array}$ \\
\hline $\begin{array}{l}\text { ) Hours work } \\
\text { per week }\end{array}$ & -- & -- & -- & $\begin{array}{c}0.0047 \\
(0.0011)\end{array}$ & -- \\
\hline $\begin{array}{l}\text { Industry } \\
\text { dummies? }\end{array}$ & No & No & Yes & Yes & Yes \\
\hline Pseudo- $R^{2}$ & 0.06 & 0.07 & 0.12 & 0.14 & 0.19 \\
\hline
\end{tabular}

Notes:

a. Median regression is performed on 1323 observations on the change in log wages from 1990 to 1991.

b. When included, the 27 industry dummies are jointly significant at the 1\% level. 
c. The omitted education category is apprenticeship. The omitted moving category is stay with same firm. 
Table 3: Determinants of Wage Growth at Different Quantiles 1990-1991, 1991-1996

(Standard Errors in Parentheses)

\begin{tabular}{|c|c|c|c|c|}
\hline & (1) & (2) & (3) & $(4)$ \\
\hline & \multicolumn{2}{|c|}{$1990-1991$} & \multicolumn{2}{|c|}{$1991-1996$} \\
\hline & $\begin{array}{c}.25 \\
\text { Quantile }\end{array}$ & $\begin{array}{c}.75 \\
\text { Quantile }\end{array}$ & $\begin{array}{c}.25 \\
\text { Quantile }\end{array}$ & $\begin{array}{c}.75 \\
\text { Quantile }\end{array}$ \\
\hline Sex (female=1) & $\begin{array}{c}0.049 \\
(0.020)\end{array}$ & $\begin{array}{c}0.024 \\
(0.017)\end{array}$ & $\begin{array}{c}0.008 \\
(0.006)\end{array}$ & $\begin{array}{c}0.009 \\
(0.007)\end{array}$ \\
\hline Age & $\begin{array}{l}-0.0007 \\
(0.0013)\end{array}$ & $\begin{array}{l}-0.0002 \\
(0.0012)\end{array}$ & $\begin{array}{l}-0.0003 \\
(0.0003)\end{array}$ & $\begin{array}{l}-0.0013 \\
(0.0004)\end{array}$ \\
\hline $\begin{array}{l}\text { General } \\
\text { schooling? }\end{array}$ & $\begin{array}{c}0.073 \\
(0.089)\end{array}$ & $\begin{array}{c}0.130 \\
(0.050)\end{array}$ & $\begin{array}{l}-0.017 \\
(0.024)\end{array}$ & $\begin{array}{c}0.056 \\
(0.036)\end{array}$ \\
\hline University? & $\begin{array}{l}-0.039 \\
(0.024)\end{array}$ & $\begin{array}{l}-0.055 \\
(0.025)\end{array}$ & $\begin{array}{c}0.020 \\
(0.008)\end{array}$ & $\begin{array}{c}0.019 \\
(0.010)\end{array}$ \\
\hline $\begin{array}{l}\text { Vocational } \\
\text { training? }\end{array}$ & $\begin{array}{c}0.008 \\
(0.021)\end{array}$ & $\begin{array}{l}-0.020 \\
(0.020)\end{array}$ & $\begin{array}{c}0.007 \\
(0.005)\end{array}$ & $\begin{array}{c}0.003 \\
(0.007)\end{array}$ \\
\hline Tenure/1000 & $\begin{array}{l}-0.101 \\
(0.100)\end{array}$ & $\begin{array}{c}-0.162 \\
(0.093)\end{array}$ & $\begin{array}{c}0.023 \\
(0.027)\end{array}$ & $\begin{array}{c}0.032 \\
(0.035)\end{array}$ \\
\hline Working in west? & -- & -- & $\begin{array}{l}-0.027 \\
(0.010)\end{array}$ & $\begin{array}{l}-0.034 \\
(0.013)\end{array}$ \\
\hline $\begin{array}{l}\text { ) Working in } \\
\text { west? }\end{array}$ & $\begin{array}{c}0.262 \\
(0.098)\end{array}$ & $\begin{array}{c}0.458 \\
(0.123)\end{array}$ & $\begin{array}{c}0.067 \\
(0.026)\end{array}$ & $\begin{array}{c}0.069 \\
(0.036)\end{array}$ \\
\hline $\begin{array}{l}\text { Move, } \\
\text { voluntarily? }\end{array}$ & $\begin{array}{c}0.065 \\
(0.049)\end{array}$ & $\begin{array}{c}0.256 \\
(0.081)\end{array}$ & $\begin{array}{l}-0.084 \\
(0.025)\end{array}$ & $\begin{array}{c}0.164 \\
(0.030)\end{array}$ \\
\hline $\begin{array}{l}\text { Move, } \\
\text { involuntarily? }\end{array}$ & $\begin{array}{l}-0.020 \\
(0.043)\end{array}$ & $\begin{array}{c}0.078 \\
(0.054)\end{array}$ & $\begin{array}{l}-0.096 \\
(0.025)\end{array}$ & $\begin{array}{c}0.040 \\
(0.023)\end{array}$ \\
\hline $\begin{array}{l}\text { Move, reason } \\
\text { unknown? }\end{array}$ & $\begin{array}{r}0.165 \\
(0.196) \\
\end{array}$ & $\begin{array}{r}0.334 \\
(0.247) \\
\end{array}$ & $\begin{array}{l}-0.009 \\
(0.020) \\
\end{array}$ & $\begin{array}{r}0.058 \\
(0.072) \\
\end{array}$ \\
\hline Pseudo $R^{2}$ & 0.07 & 0.19 & 0.03 & 0.10 \\
\hline Observations & \multicolumn{2}{|c|}{1323} & \multicolumn{2}{|r|}{5653} \\
\hline
\end{tabular}

Notes:

a. Quantile regression at the .25 and .75 quantiles is performed on year to year change in log wages.

b. 27 industry dummies are included, and are jointly significant at the 1\% level.

c. Year dummies are included in columns 3 and 4.

d. The omitted education category is apprenticeship. The omitted 
moving category is stay with same firm. 
Table 4: Determinants of Wage Growth 1991-1996 (Standard Errors in Parentheses)

\begin{tabular}{|c|c|c|c|c|c|}
\hline & (1) & $(2)$ & (3) & (4) & $(5)$ \\
\hline Log wage & -- & -- & -- & -- & $\begin{array}{c}-0.202 \\
(0.013)\end{array}$ \\
\hline Sex (female $=1)$ & $\begin{array}{l}0.013 \\
(0.005)\end{array}$ & $\begin{array}{l}0.012 \\
(0.005)\end{array}$ & $\begin{array}{c}0.011 \\
(0.005)\end{array}$ & $\begin{array}{l}0.010 \\
(0.005)\end{array}$ & $\begin{array}{l}-0.012 \\
(0.005)\end{array}$ \\
\hline Age & $\begin{array}{l}-0.0007 \\
(0.0003 \\
\quad\end{array}$ & $\begin{array}{l}-0.0009 \\
(0.0003 \\
\quad\end{array}$ & $\begin{array}{l}-0.0010 \\
(0.0003)\end{array}$ & $\begin{array}{c}-0.0010 \\
(0.0003)\end{array}$ & $\begin{array}{c}-0.0005 \\
(0.0003)\end{array}$ \\
\hline $\begin{array}{l}\text { General } \\
\text { schooling? }\end{array}$ & $\begin{array}{l}0.018 \\
(0.029)\end{array}$ & $\begin{array}{l}0.018 \\
(0.028)\end{array}$ & $\begin{array}{l}0.016 \\
(0.023)\end{array}$ & $\begin{array}{c}0.024 \\
(0.021)\end{array}$ & $\begin{array}{l}-0.008 \\
(0.018)\end{array}$ \\
\hline University? & $\begin{array}{l}0.027 \\
(0.007)\end{array}$ & $\begin{array}{l}0.028 \\
(0.006)\end{array}$ & $\begin{array}{l}0.016 \\
(0.007)\end{array}$ & $\begin{array}{c}0.018 \\
(0.007)\end{array}$ & $\begin{array}{l}0.099 \\
(0.010)\end{array}$ \\
\hline $\begin{array}{l}\text { Vocational } \\
\text { training? }\end{array}$ & $\begin{array}{l}0.005 \\
(0.006)\end{array}$ & $\begin{array}{l}0.005 \\
(0.005)\end{array}$ & $\begin{array}{c}0.001 \\
(0.006)\end{array}$ & $\begin{array}{l}-0.000 \\
(0.006)\end{array}$ & $\begin{array}{l}0.038 \\
(0.006)\end{array}$ \\
\hline ) Tenure/1000 & $\begin{array}{l}0.078 \\
(0.118)\end{array}$ & -- & -- & -- & -- \\
\hline Tenure/1000 & -- & $\begin{array}{l}0.040 \\
(0.024)\end{array}$ & $\begin{array}{l}0.024 \\
(0.028)\end{array}$ & $\begin{array}{c}0.035 \\
(0.030)\end{array}$ & $\begin{array}{c}0.094 \\
(0.026)\end{array}$ \\
\hline $\begin{array}{l}\text { Working in } \\
\text { west? }\end{array}$ & $\begin{array}{l}-0.055 \\
(0.007)\end{array}$ & $\begin{array}{l}-0.050 \\
(0.007)\end{array}$ & $\begin{array}{l}-0.040 \\
(0.007)\end{array}$ & $\begin{array}{l}-0.039 \\
(0.007)\end{array}$ & $\begin{array}{c}0.009 \\
(0.008)\end{array}$ \\
\hline $\begin{array}{l}\text { ) Working in } \\
\text { west? }\end{array}$ & $\begin{array}{l}0.048 \\
(0.040)\end{array}$ & $\begin{array}{l}0.058 \\
(0.042)\end{array}$ & $\begin{array}{c}0.058 \\
(0.041)\end{array}$ & $\begin{array}{c}0.059 \\
(0.046)\end{array}$ & $\begin{array}{c}0.074 \\
(0.032)\end{array}$ \\
\hline $\begin{array}{l}\text { Move, } \\
\text { voluntarily? }\end{array}$ & -- & $\begin{array}{l}0.025 \\
(0.024)\end{array}$ & $\begin{array}{l}0.029 \\
(0.024)\end{array}$ & $\begin{array}{c}0.015 \\
(0.027)\end{array}$ & $\begin{array}{l}0.006 \\
(0.023)\end{array}$ \\
\hline $\begin{array}{l}\text { Move, } \\
\text { involuntarily? }\end{array}$ & -- & $\begin{array}{l}-0.045 \\
(0.021)\end{array}$ & $\begin{array}{l}-0.028 \\
(0.023)\end{array}$ & $\begin{array}{l}-0.035 \\
(0.024)\end{array}$ & $\begin{array}{l}-0.039 \\
(0.020)\end{array}$ \\
\hline $\begin{array}{l}\text { Move, reason } \\
\text { unknown? }\end{array}$ & -- & $\begin{array}{l}0.029 \\
(0.037)\end{array}$ & $\begin{array}{c}0.022 \\
(0.034)\end{array}$ & $\begin{array}{c}0.021 \\
(0.041)\end{array}$ & $\begin{array}{c}0.002 \\
(0.026)\end{array}$ \\
\hline $\begin{array}{l}\text { ) Hours work } \\
\text { per week }\end{array}$ & -- & -- & -- & $\begin{array}{c}0.0030 \\
(0.0006)\end{array}$ & -- \\
\hline $\begin{array}{l}\text { Industry } \\
\text { dummies? }\end{array}$ & No & No & Yes & Yes & Yes \\
\hline Pseudo- $R^{2}$ & 0.04 & 0.04 & 0.05 & 0.06 & 0.10 \\
\hline
\end{tabular}

Notes:

a. Median regression is performed on 5653 observations on the yearly change in log wages from 1991 to 1996.

b. Year dummies are included. 
c. When included, the 27 industry dummies are jointly significant at the 1\% level.

d. The omitted education category is apprenticeship. The omitted moving category is stay with same firm. 
Table 5: Wage Growth Determinants for Stayers and Movers 1990-1991 (Standard Errors in Parentheses)

\begin{tabular}{|c|c|c|c|c|c|}
\hline & (1) & $\begin{array}{c}\text { (2) } \\
\text { Stayers }\end{array}$ & (3) & $\begin{array}{l}\text { (4) } \\
\text { Mover }\end{array}$ & (5) \\
\hline Log wage & -- & -- & $\begin{array}{l}-0.297 \\
(0.037)\end{array}$ & -- & $\begin{array}{l}-0.588 \\
(0.099)\end{array}$ \\
\hline Sex (female=1) & $\begin{array}{c}0.014 \\
(0.011)\end{array}$ & $\begin{array}{c}0.047 \\
(0.016)\end{array}$ & $\begin{array}{l}-0.016 \\
(0.015)\end{array}$ & $\begin{array}{l}-0.015 \\
(0.073)\end{array}$ & $\begin{array}{l}-0.137 \\
(0.055)\end{array}$ \\
\hline Age & $\begin{array}{l}-0.0001 \\
(0.0010)\end{array}$ & $\begin{array}{l}-0.0004 \\
(0.0008)\end{array}$ & $\begin{array}{l}-0.0002 \\
(0.0008)\end{array}$ & $\begin{array}{l}-0.0095 \\
(0.0050)\end{array}$ & $\begin{array}{r}-0.0062 \\
(0.0037)\end{array}$ \\
\hline General schooling? & $\begin{array}{c}0.085 \\
(0.052)\end{array}$ & $\begin{array}{c}0.095 \\
(0.058)\end{array}$ & $\begin{array}{l}-0.024 \\
(0.052)\end{array}$ & $\begin{array}{c}0.820 \\
(0.476)\end{array}$ & $\begin{array}{c}0.110 \\
(0.289)\end{array}$ \\
\hline University? & $\begin{array}{l}-0.077 \\
(0.014)\end{array}$ & $\begin{array}{l}-0.051 \\
(0.022)\end{array}$ & $\begin{array}{c}0.053 \\
(0.025)\end{array}$ & $\begin{array}{l}-0.050 \\
(0.089)\end{array}$ & $\begin{array}{c}0.201 \\
(0.087)\end{array}$ \\
\hline $\begin{array}{l}\text { Vocational } \\
\text { training? }\end{array}$ & $\begin{array}{l}-0.042 \\
(0.012)\end{array}$ & $\begin{array}{l}-0.019 \\
(0.015)\end{array}$ & $\begin{array}{c}0.056 \\
(0.017)\end{array}$ & $\begin{array}{l}-0.046 \\
(0.074)\end{array}$ & $\begin{array}{c}0.168 \\
(0.062)\end{array}$ \\
\hline Tenure/1000 & $\begin{array}{l}-0.014 \\
(0.073)\end{array}$ & $\begin{array}{l}-0.064 \\
(0.073)\end{array}$ & $\begin{array}{c}0.061 \\
(0.069)\end{array}$ & $\begin{array}{c}0.192 \\
(0.358)\end{array}$ & $\begin{array}{c}0.245 \\
(0.293)\end{array}$ \\
\hline ) Working in west? & $\begin{array}{c}0.201 \\
(0.227)\end{array}$ & $\begin{array}{c}0.051 \\
(0.230)\end{array}$ & $\begin{array}{c}0.238 \\
(0.196)\end{array}$ & $\begin{array}{c}0.264 \\
(0.081)\end{array}$ & $\begin{array}{c}0.351 \\
(0.069)\end{array}$ \\
\hline $\begin{array}{l}\text { Stay, growing } \\
\text { firm? }\end{array}$ & $\begin{array}{c}0.151 \\
(0.058)\end{array}$ & $\begin{array}{c}0.034 \\
(0.033)\end{array}$ & $\begin{array}{c}0.016 \\
(0.033)\end{array}$ & -- & -- \\
\hline $\begin{array}{l}\text { Stay, shrinking } \\
\text { firm? }\end{array}$ & $\begin{array}{c}0.012 \\
(0.012)\end{array}$ & $\begin{array}{c}0.017 \\
(0.014)\end{array}$ & $\begin{array}{c}0.006 \\
(0.013)\end{array}$ & -- & -- \\
\hline $\begin{array}{l}\text { Stay, unknown } \\
\text { firm type? }\end{array}$ & $\begin{array}{c}0.010 \\
(0.031)\end{array}$ & $\begin{array}{l}-0.016 \\
(0.033)\end{array}$ & $\begin{array}{c}0.012 \\
(0.035)\end{array}$ & -- & -- \\
\hline $\begin{array}{l}\text { Move, } \\
\text { involuntarily? }\end{array}$ & -- & -- & -- & $\begin{array}{l}-0.034 \\
(0.065)\end{array}$ & $\begin{array}{l}-0.116 \\
(0.062)\end{array}$ \\
\hline $\begin{array}{l}\text { Move, reason } \\
\text { unknown? }\end{array}$ & -- & -- & -- & $\begin{array}{c}0.104 \\
(0.234)\end{array}$ & $\begin{array}{l}-0.219 \\
(0.171)\end{array}$ \\
\hline $\begin{array}{l}\text { Hours worked } \\
\text { per week }\end{array}$ & -- & $\begin{array}{c}0.0040 \\
(0.0011)\end{array}$ & -- & -- & -- \\
\hline Industry dummies? & No & Yes & Yes & Yes & Yes \\
\hline Pseudo- $R^{2}$ & 0.02 & 0.12 & 0.17 & 0.23 & 0.34 \\
\hline Observations & & 1124 & & & \\
\hline
\end{tabular}

Notes:

a. Median regression is performed on the yearly change in log wage.

b. Columns 2 and 3 include 27 industry dummies which are jointly significant at the 1\% level. Columns 4 and 5 include 11 more aggregated industry dummies, jointly insignificant.

c. The omitted education category is apprenticeship. The omitted staying category in columns $1-3$ is stay with a stable firm. The omitted moving category in 
columns 4-5 is move voluntarily. 
Table 6: Wage Growth Determinants for Stayers and Movers 1991-1996 (Standard Errors in Parentheses)

\begin{tabular}{|c|c|c|c|c|c|}
\hline & (1) & $\begin{array}{c}\text { (2) } \\
\text { Stayers }\end{array}$ & (3) & \multicolumn{2}{|c|}{ Movers } \\
\hline Log wage & -- & -- & $\begin{array}{l}-0.173 \\
(0.013)\end{array}$ & -- & $\begin{array}{l}-0.646 \\
(0.085)\end{array}$ \\
\hline Sex (female=1) & $\begin{array}{c}0.012 \\
(0.005)\end{array}$ & $\begin{array}{c}0.011 \\
(0.005)\end{array}$ & $\begin{array}{l}-0.012 \\
(0.005)\end{array}$ & $\begin{array}{c}0.033 \\
(0.037)\end{array}$ & $\begin{array}{l}-0.112 \\
(0.040)\end{array}$ \\
\hline Age & $\begin{array}{l}-0.0009 \\
(0.0003)\end{array}$ & $\begin{array}{c}-0.0009 \\
(0.0003)\end{array}$ & $\begin{array}{c}-0.0004 \\
(0.0003)\end{array}$ & $\begin{array}{c}-0.0013 \\
(0.0021)\end{array}$ & $\begin{array}{c}0.0007 \\
(0.0020)\end{array}$ \\
\hline General schooling? & $\begin{array}{c}0.020 \\
(0.029)\end{array}$ & $\begin{array}{c}0.025 \\
(0.020)\end{array}$ & $\begin{array}{l}-0.003 \\
(0.018)\end{array}$ & $\begin{array}{c}0.069 \\
(0.136)\end{array}$ & $\begin{array}{l}-0.101 \\
(0.081)\end{array}$ \\
\hline University? & $\begin{array}{c}0.030 \\
(0.006)\end{array}$ & $\begin{array}{c}0.017 \\
(0.007)\end{array}$ & $\begin{array}{c}0.084 \\
(0.010)\end{array}$ & $\begin{array}{c}0.018 \\
(0.057)\end{array}$ & $\begin{array}{c}0.311 \\
(0.061)\end{array}$ \\
\hline $\begin{array}{l}\text { Vocational } \\
\text { training? }\end{array}$ & $\begin{array}{c}0.008 \\
(0.005)\end{array}$ & $\begin{array}{c}0.000 \\
(0.006)\end{array}$ & $\begin{array}{c}0.032 \\
(0.006)\end{array}$ & $\begin{array}{l}-0.022 \\
(0.036)\end{array}$ & $\begin{array}{c}0.085 \\
(0.042)\end{array}$ \\
\hline Tenure/1000 & $\begin{array}{c}0.042 \\
(0.025)\end{array}$ & $\begin{array}{c}0.032 \\
(0.030)\end{array}$ & $\begin{array}{c}0.095 \\
(0.027)\end{array}$ & $\begin{array}{l}-0.107 \\
(0.189)\end{array}$ & $\begin{array}{l}-0.122 \\
(0.181)\end{array}$ \\
\hline Working in west? & $\begin{array}{l}-0.046 \\
(0.006)\end{array}$ & $\begin{array}{l}-0.035 \\
(0.007)\end{array}$ & $\begin{array}{c}0.004 \\
(0.009)\end{array}$ & $\begin{array}{l}-0.109 \\
(0.051)\end{array}$ & $\begin{array}{c}0.086 \\
(0.058)\end{array}$ \\
\hline ) Working in west? & $\begin{array}{l}0.005 \\
(0.028)\end{array}$ & $\begin{array}{l}-0.002 \\
(0.033)\end{array}$ & $\begin{array}{c}0.038 \\
(0.026)\end{array}$ & $\begin{array}{c}0.154 \\
(0.061)\end{array}$ & $\begin{array}{c}0.180 \\
(0.053)\end{array}$ \\
\hline $\begin{array}{l}\text { Stay, growing } \\
\text { firm? }\end{array}$ & $\begin{array}{c}0.001 \\
(0.007)\end{array}$ & $\begin{array}{l}-0.004 \\
(0.008)\end{array}$ & $\begin{array}{l}-0.000 \\
(0.008)\end{array}$ & -- & -- \\
\hline $\begin{array}{l}\text { Stay, shrinking } \\
\text { firm? }\end{array}$ & $\begin{array}{l}-0.006 \\
(0.007)\end{array}$ & $\begin{array}{l}-0.006 \\
(0.006)\end{array}$ & $\begin{array}{l}-0.011 \\
(0.006)\end{array}$ & -- & -- \\
\hline $\begin{array}{l}\text { Stay, unknown } \\
\text { firm type? }\end{array}$ & $\begin{array}{c}0.022 \\
(0.014)\end{array}$ & $\begin{array}{c}0.017 \\
(0.014)\end{array}$ & $\begin{array}{c}0.014 \\
(0.016)\end{array}$ & -- & -- \\
\hline $\begin{array}{l}\text { Move, } \\
\text { involuntarily? }\end{array}$ & -- & -- & -- & $\begin{array}{l}-0.074 \\
(0.035)\end{array}$ & $\begin{array}{l}-0.043 \\
(0.036)\end{array}$ \\
\hline $\begin{array}{l}\text { Move, reason } \\
\text { unknown? }\end{array}$ & -- & -- & -- & $\begin{array}{l}0.016 \\
(0.045)\end{array}$ & $\begin{array}{c}0.050 \\
(0.044)\end{array}$ \\
\hline $\begin{array}{l}\text { Hours worked } \\
\text { per week }\end{array}$ & -- & $\begin{array}{c}0.0023 \\
(0.0005)\end{array}$ & -- & -- & -- \\
\hline Industry dummies? & No & Yes & Yes & Yes & Yes \\
\hline Pseudo- $R^{2}$ & 0.05 & 0.06 & 0.10 & 0.07 & 0.22 \\
\hline Observations & & 5110 & & & \\
\hline
\end{tabular}

Notes:

a. Median regression is performed on the yearly change in log wages.

b. Columns 2 and 3 include 27 industry dummies which are jointly significant at the 1\% level. Columns 4 and 5 include 11 more aggregated industry dummies, jointly insignificant. 
c. The omitted education category is apprenticeship. The omitted staying category in columns $1-3$ is stay with a stable firm. The omitted moving category in columns 4-5 is move voluntarily. 
Table 7: Effect of Wage Bargaining on Wage Growth 1994-1996 (Standard Errors in Parentheses)

\begin{tabular}{lccc}
\hline \hline & $(1)$ & $(2)$ & $(3)$ \\
In uncovered group & 0.028 & 0.017 & 0.042 \\
& $(0.028)$ & $(0.027)$ & $(0.027)$ \\
Wages set freely & -0.021 & -0.024 & -0.035 \\
& $(0.008)$ & $(0.008)$ & $(0.008)$ \\
Not bargained, & -0.058 & -0.056 & -0.053 \\
reason why not is missing & $(0.034)$ & $(0.033)$ & $(0.031)$ \\
Bargaining information & -0.004 & -0.002 & -0.011 \\
missing & $(0.017)$ & $(0.017)$ & $(0.016)$ \\
Industry dummies? & Yes & Yes & Yes \\
Log wage included? & No & No & Yes \\
) Hours worked per week & No & Yes & Yes \\
included? & & 0.03 & 0.04 \\
\hline Pseudo-R & & 0.03 & \\
\hline \hline
\end{tabular}

Notes:

a. Median regression for 1990 stayers is performed on the pairs of years 1994-1995 and 1995-1996.

b. Regressions include all the covariates of Table 6 column 2 . 
Appendix Table: Wage Growth Determinants For Western Sample 1990-6 (Standard Errors in Parentheses)

\begin{tabular}{|c|c|c|c|c|c|}
\hline & (1) & $(2)$ & (3) & (4) & ( 5 ) \\
\hline & \multicolumn{3}{|c|}{ Whole Sample } & Stayers & Movers \\
\hline Log wage & -- & -- & $\begin{array}{l}-0.045 \\
(0.004)\end{array}$ & $\begin{array}{l}-0.032 \\
(0.003)\end{array}$ & $\begin{array}{l}-0.478 \\
(0.038)\end{array}$ \\
\hline Sex (female=1) & $\begin{array}{c}0.002 \\
(0.002)\end{array}$ & $\begin{array}{c}0.001 \\
(0.002)\end{array}$ & $\begin{array}{l}-0.013 \\
(0.002)\end{array}$ & $\begin{array}{l}-0.010 \\
(0.002)\end{array}$ & $\begin{array}{l}-0.149 \\
(0.028)\end{array}$ \\
\hline Age & $\begin{array}{l}-0.0009 \\
(0.0001)\end{array}$ & $\begin{array}{l}-0.0009 \\
(0.0001)\end{array}$ & $\begin{array}{l}-0.0008 \\
(0.0001)\end{array}$ & $\begin{array}{l}-0.0008 \\
(0.0001)\end{array}$ & $\begin{array}{c}0.0015 \\
(0.0015)\end{array}$ \\
\hline $\begin{array}{l}\text { General German } \\
\text { schooling? }\end{array}$ & $\begin{array}{l}-0.003 \\
(0.003)\end{array}$ & $\begin{array}{l}-0.001 \\
(0.003)\end{array}$ & $\begin{array}{l}-0.006 \\
(0.003)\end{array}$ & $\begin{array}{l}-0.006 \\
(0.003)\end{array}$ & $\begin{array}{l}-0.007 \\
(0.030)\end{array}$ \\
\hline $\begin{array}{l}\text { General foreign } \\
\text { schooling? }\end{array}$ & $\begin{array}{l}-0.011 \\
(0.004)\end{array}$ & $\begin{array}{l}-0.010 \\
(0.004)\end{array}$ & $\begin{array}{l}-0.016 \\
(0.004)\end{array}$ & $\begin{array}{l}-0.015 \\
(0.004)\end{array}$ & $\begin{array}{l}-0.047 \\
(0.046)\end{array}$ \\
\hline University? & $\begin{array}{c}0.008 \\
(0.003)\end{array}$ & $\begin{array}{c}0.008 \\
(0.003)\end{array}$ & $\begin{array}{c}0.029 \\
(0.003)\end{array}$ & $\begin{array}{c}0.022 \\
(0.003)\end{array}$ & $\begin{array}{c}0.275 \\
(0.041)\end{array}$ \\
\hline $\begin{array}{l}\text { Vocational } \\
\text { training? }\end{array}$ & $\begin{array}{l}-0.003 \\
(0.002)\end{array}$ & $\begin{array}{l}-0.003 \\
(0.002)\end{array}$ & $\begin{array}{c}0.001 \\
(0.003)\end{array}$ & $\begin{array}{l}-0.000 \\
(0.003)\end{array}$ & $\begin{array}{c}0.007 \\
(0.032)\end{array}$ \\
\hline $\begin{array}{l}\text { Civil service } \\
\text { training? }\end{array}$ & $\begin{array}{l}-0.001 \\
(0.003)\end{array}$ & $\begin{array}{l}-0.001 \\
(0.004)\end{array}$ & $\begin{array}{c}0.005 \\
(0.004)\end{array}$ & $\begin{array}{c}0.005 \\
(0.004)\end{array}$ & $\begin{array}{c}0.126 \\
(0.125)\end{array}$ \\
\hline Tenure/1000 & $\begin{array}{l}-0.027 \\
(0.011)\end{array}$ & $\begin{array}{l}-0.026 \\
(0.011)\end{array}$ & $\begin{array}{c}0.005 \\
(0.013)\end{array}$ & $\begin{array}{l}-0.006 \\
(0.012)\end{array}$ & $\begin{array}{c}0.017 \\
(0.284)\end{array}$ \\
\hline $\begin{array}{l}\text { Stay, growing } \\
\text { firm? }\end{array}$ & -- & -- & -- & $\begin{array}{c}0.018 \\
(0.004)\end{array}$ & -- \\
\hline $\begin{array}{l}\text { Stay, shrinking } \\
\text { firm? }\end{array}$ & -- & -- & -- & $\begin{array}{c}0.005 \\
(0.002)\end{array}$ & -- \\
\hline $\begin{array}{l}\text { Stay, unknown } \\
\text { firm type? }\end{array}$ & -- & -- & -- & $\begin{array}{c}0.005 \\
(0.006)\end{array}$ & -- \\
\hline $\begin{array}{l}\text { Move, } \\
\text { voluntarily? }\end{array}$ & $\begin{array}{c}0.052 \\
(0.012)\end{array}$ & $\begin{array}{c}0.043 \\
(0.012)\end{array}$ & $\begin{array}{c}0.050 \\
(0.013)\end{array}$ & -- & -- \\
\hline $\begin{array}{l}\text { Move, } \\
\text { involuntarily? }\end{array}$ & $\begin{array}{l}-0.014 \\
(0.016)\end{array}$ & $\begin{array}{l}-0.015 \\
(0.015)\end{array}$ & $\begin{array}{l}-0.018 \\
(0.014)\end{array}$ & -- & $\begin{array}{l}-0.075 \\
(0.028)\end{array}$ \\
\hline $\begin{array}{l}\text { Move, reason } \\
\text { unknown? }\end{array}$ & $\begin{array}{c}0.133 \\
(0.050)\end{array}$ & $\begin{array}{c}0.148 \\
(0.049)\end{array}$ & $\begin{array}{c}0.104 \\
(0.050)\end{array}$ & -- & $\begin{array}{l}-0.014 \\
(0.040)\end{array}$ \\
\hline $\begin{array}{l}\text { Hours worked } \\
\text { per week }\end{array}$ & -- & $\begin{array}{c}0.0033 \\
(0.0004)\end{array}$ & -- & -- & -- \\
\hline Industry dummies? & Yes & Yes & Yes & Yes & Yes \\
\hline Pseudo- $\mathrm{R}^{2}$ & 0.01 & 0.02 & 0.02 & 0.02 & 0.20 \\
\hline Observations & & 14603 & & 13608 & 995 \\
\hline
\end{tabular}

\section{Notes:}

a. Median regression is performed on the yearly change in log wage.

b. Year dummies are included.

c. Columns 1-4 include 27 industry dummies which are jointly significant at the 
1\% level. Column 5 includes 11 more aggregated industry dummies, jointly insignificant.

d. The omitted education category is apprenticeship. 

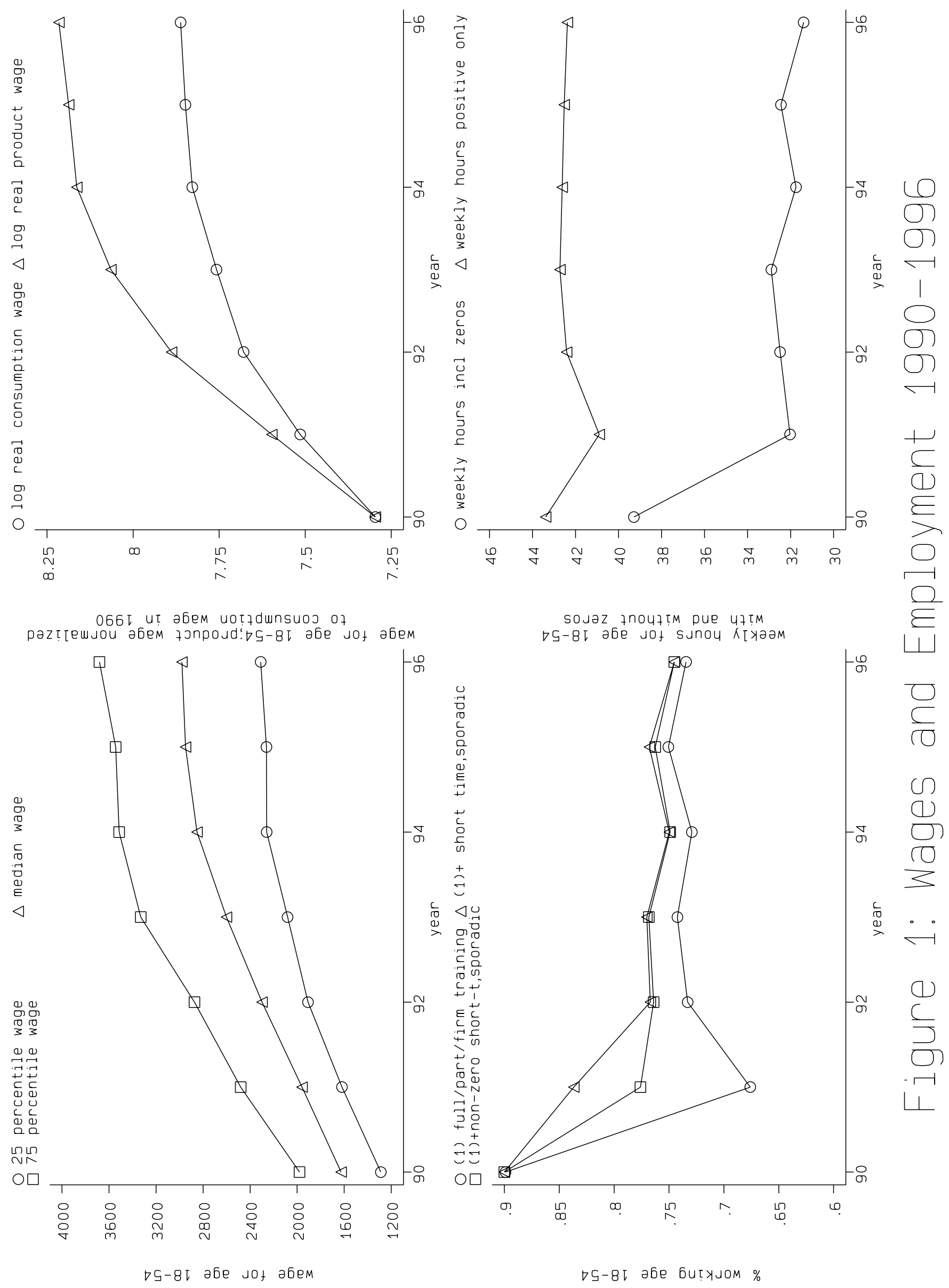


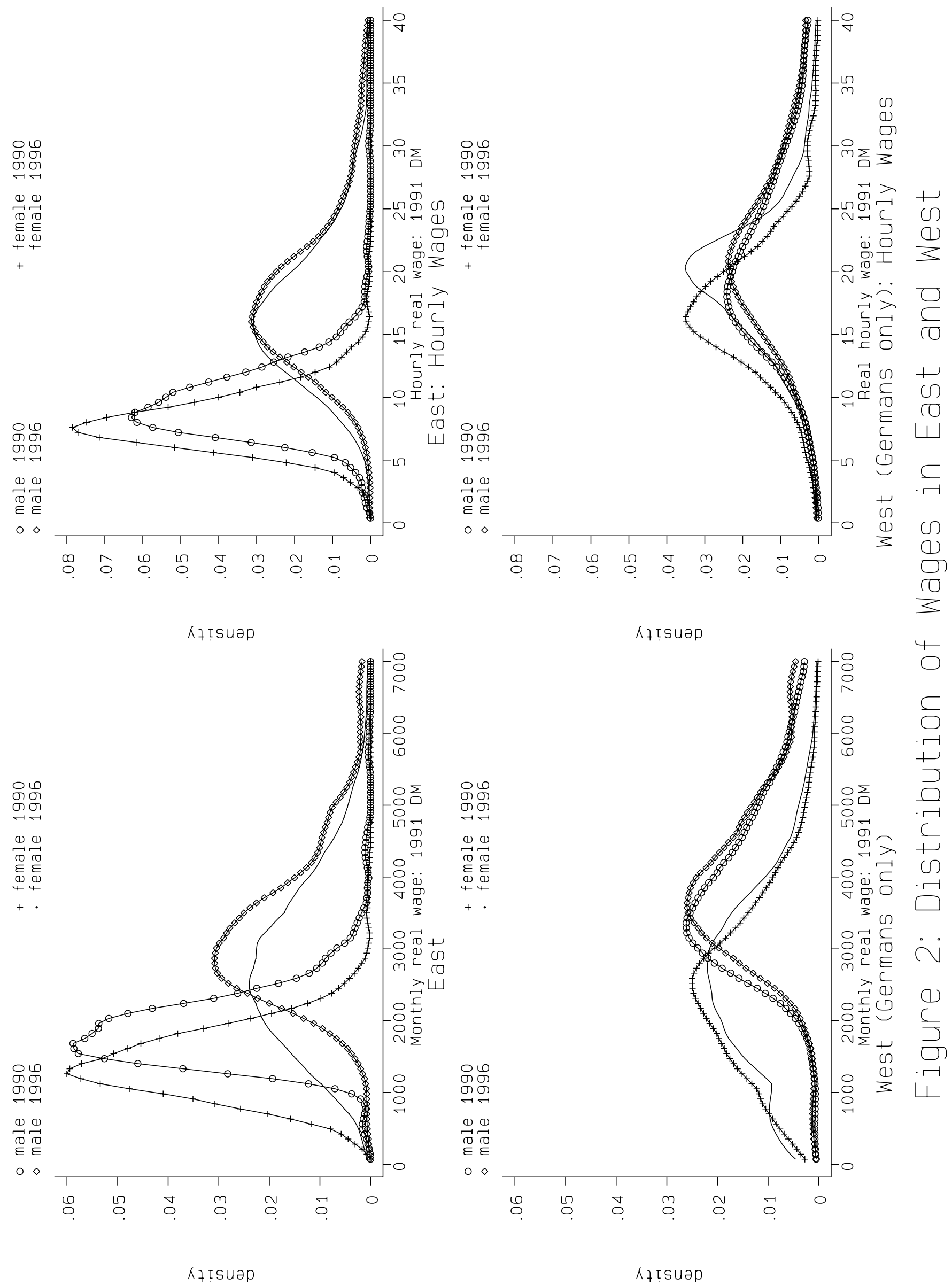




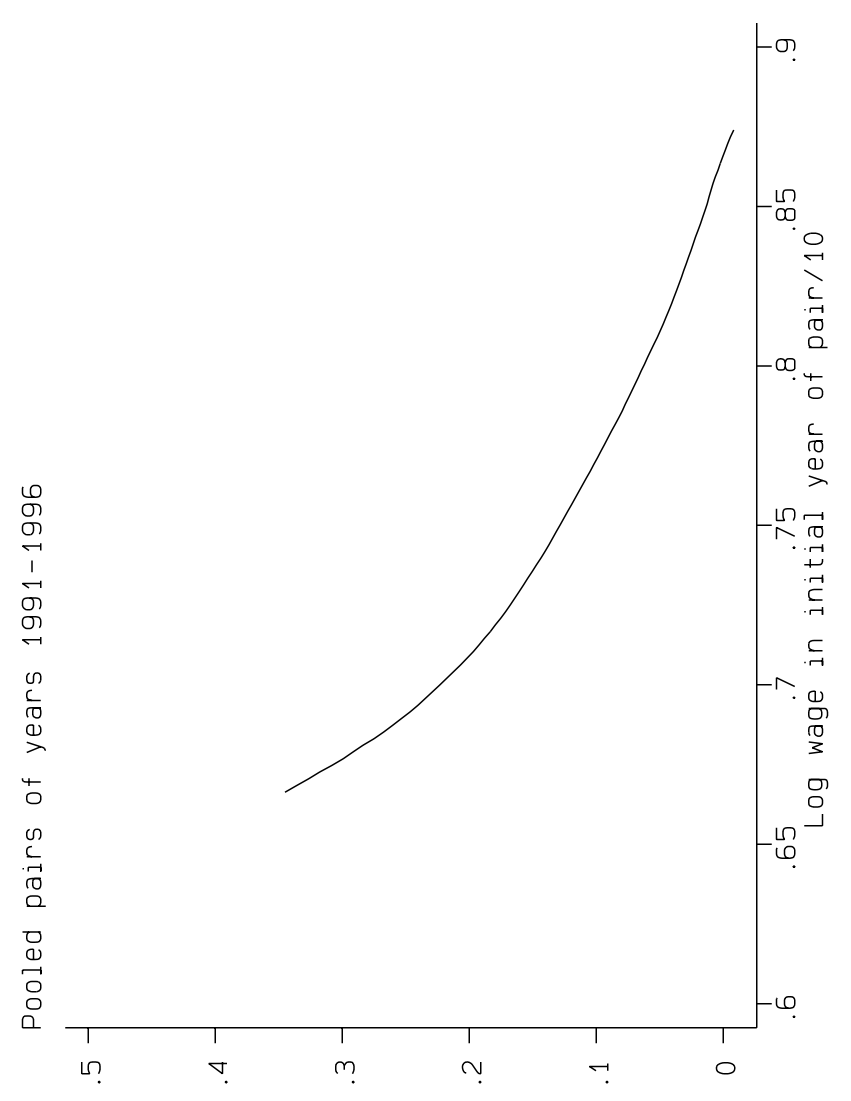

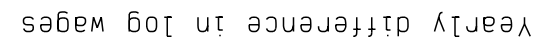

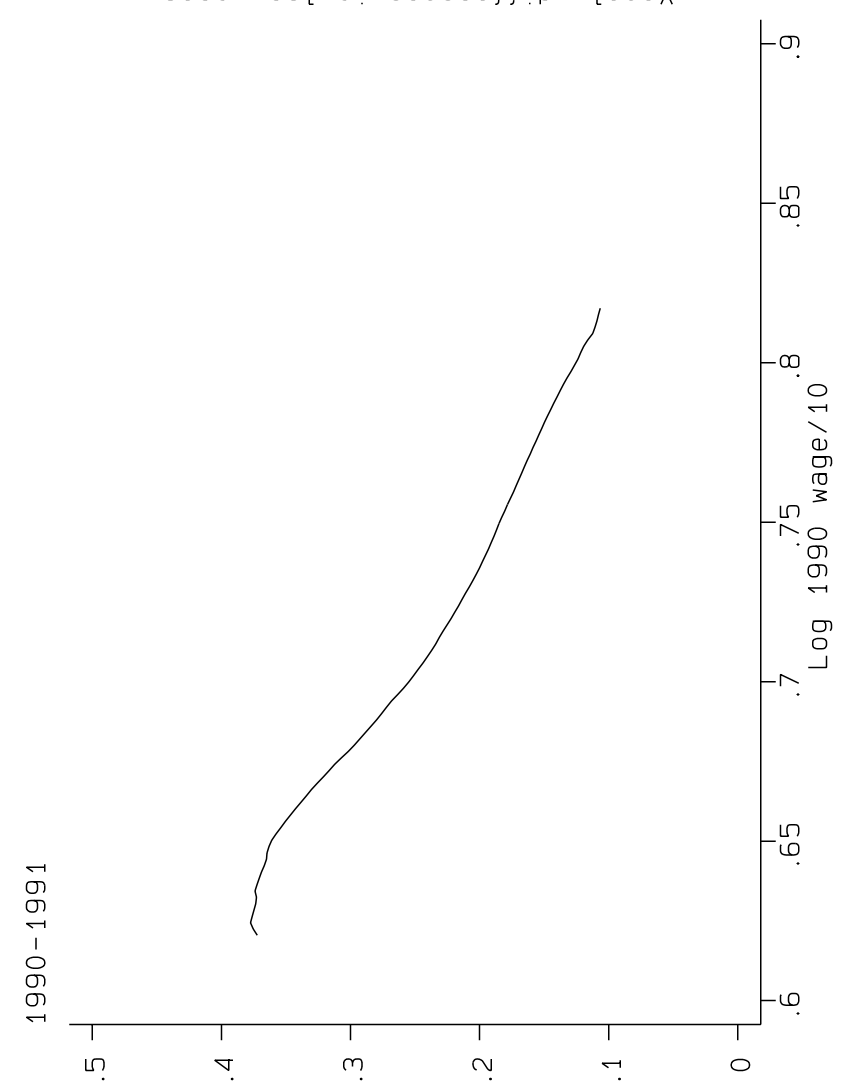

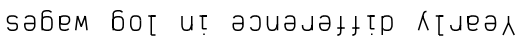

(1)

$\square$

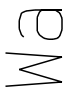

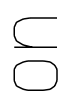

$\frac{5}{\frac{1}{b}}$

(1)

$\square$

$\frac{\pi}{3}$

4

$\square$

$-\square$

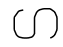

( $)$

(1)

5

(1)

I

$\circlearrowleft$

$\stackrel{+1}{1+1}$

(1)

$\varepsilon$

$\frac{c}{\pi}$

$\frac{\square}{\sum_{0}^{1}}$

m

(1)

$\bar{\square}$

$-\square$

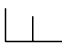

